\title{
İdari Coğrafya Açısından Bir İnceleme: Afyonkarahisar İli
}

\section{A Review in Terms of Administrative Geography: Afyonkarahisar Province}

\author{
Dr. Öğr. Üyesi Fatih AYHAN (D) 1
}

\section{$\ddot{O} z$}

Ege Bölgesi'nin İç Batı Anadolu Bölümü'ne yer alan Afyonkarahisar ili bulunduğu konum itibariyle Ege, Akdeniz ve İç Anadolu bölgelerine ait illerle çevrelenmiştir. Coğrafi konumunun etkisiyle bahsi geçen bölgeler arasında geçiş özelliği gösteren Afyonkarahisar, Osmanlı Dönemi’nde önemli bir sancak idari birimini oluşturmuş iken bu özelliğini Cumhuriyet Dönemi'nde de il idari birimi olarak devam ettirmiştir. Çalışma sahasının yüzölçümünün oldukça geniş ve dağlık bir topografyaya sahip olması, ildeki idari örgütlenmeyi de etkilemiştir. İl içerisinde etki sahaları dar idari birimler oluşturulurken, bazı yerleşmeler ulaşım etkisine bağlı olarak Afyonkarahisar il merkezi yerine, komşu illerin etki sahası içine girmektedir. Türkiye'nin mevcut idari bölünüş sistemine göre iller en büyük idari birimi oluşturmaktadır. Afyonkarahisar $14.016 \mathrm{~km}^{2}$ yüzölçümü ile ülkemizin 13. büyük ili olurken, 2020 y1lı itibariyle sahip olduğu 736.912 kişilik nüfusu ile büyükşehir statüsü elde etme sınırında yer almaktadır. Diğer yandan il içerisinde mevcut durumda 18 ilçe idari ünitesi, 41 belde ve 422 köy idari ünitesi bulunmaktadır.

Anahtar Kelimeler: Afyonkarahisar, idari coğrafya, yerleşme

Makale Türü: Araştırma

\begin{abstract}
The province of Afyonkarahisar, which is located in the Inner West Anatolia Section of the Aegean Region, is surrounded by provinces belonging to the Aegean, Mediterranean and Central Anatolia regions. Afyonkarahisar was an important sanjak settlement during the Ottoman Period, with the effect of its transitional geographical location between the Regions it has, while it continued this feature as a province in the Tanzimat Period and then as a provincial administrative unit in the Republic Period. The wide and mountainous topography of the working area has also affected the administrative organization in the province. While narrow administrative units are formed within the province, some settlements fall within the impact area of neighboring provinces instead of Afyonkarahisar city center due to the transportation effect. According to Turkey's current administrative division system constitutes the largest administrative unit the provinces. While Afyonkarahisar is the 13th largest city of our country with an area of $14,016 \mathrm{~km}^{2}$, it is on the border of achieving metropolitan status with its population of 736,912 as of 2020. On the other hand, there are 18 districts, 41 towns and 422 village settlements in the province.
\end{abstract}

Keywords: Afyonkarahisar, administrative geography, settlement

Paper Type: Research

\footnotetext{
${ }^{1}$ Afyon Kocatepe Üniversitesi, Fen Edebiyat Fakültesi, Coğrafya Bölümü, fayhan@aku.edu.tr.

Atıf için (to cite): Ayhan, F. (2021). İdari Coğrafya Açısından Bir inceleme: Afyonkarahisar İli Afyon Kocatepe Üniversitesi Sosyal Bilimler Dergisi, 23(3), 840-860.
} 


\section{Giriş}

Devlet sınırları ile kuşatılmış ve coğrafi mekân olarak adlandırabileceğimiz geniş ülke arazisini herhangi bir bölümleme yapmadan yönetmeye çalışmak oldukça zor bir durumdur (Özçağlar, 2003, s. 8). Bu yüzden devletler ülkelerini daha etkili ve verimli yönetebilmek, aynı zamanda saha üzerinde idari denetimi sağlayabilmek için ülkeyi yönetsel bölgelere ayırır. Mülki idari birim olarak da adlandırılan bu bölümlerin sınırları belirlenirken sahanın fiziki yer şekilleri, ekonomik potansiyeli, sosyal, kültürel ve ekonomik anlamda etki sahaları ile kamu hizmetlerine olan gereksinimleri göz önünde tutulur. Coğrafi mekân üzerinde dikkate alınan bu unsurlar yönüyle baktığımızda meselenin coğrafya bilimi ile yakından ilgili olduğu görülür.

Uluslararası ölçekte siyasi niteliğe sahip olan devletlerin egemen oldukları ülke arazilerinin yönetimiyle ilgili esasları coğrafi ortamla ilişkili olarak ele alıp inceleyen beşeri coğrafyanın alt dalına idari coğrafya denmektedir (Özçağlar, 2005, s. 3). İdari coğrafya yöneticilere idari bölümleme aşamasında yol göstericidir. Bir başka tanıma göre idari coğrafya; ulusal ve uluslararası ilişkiler ile jeopolitik potansiyellere bağlı olarak örgütlenmiş merkezi bir gücün yani devletin kendi sınırları içinde belirli bir mekânda idari özerklik ve yerleşmeler kademelenmesi gösterdiği alt siyasal yönetsel yapılanmaların mekânsal yansımalarıdır (Özzcan, 2005, s. 75).

Ülkemizde yürürlükte olan 1982 Anayasası'nın idari bölünüş ile ilgili 126. maddesine göre "Türkiye, merkezî idare kuruluşu bakımından, coğrafya durumuna, ekonomik şartlara ve kamu hizmetlerinin gereklerine göre, illere; iller de diğer kademeli bölümlere ayrılır." hükmü bulunmaktadır. Buna göre ülke toprakları ilk olarak illere, iller ilçelere ve ilçeler de köy idari alanlarına ayrılmıştır.

İdari coğrafya, ortaya koyduğu çalışmalar ve tespitlerle başta idari birimlerin yöneticileri olmak üzere ekonomistlere, ticaret ve sanayi ile uğraşan kesime büyük fayda sağlamaktadır. Diğer yandan mülki idareyi oluşturan birimlerin analizinin yapılması, ülkenin idari coğrafyasının daha yakından tanınması ve kalkınmaya dönük yapılacak bölgesel planlamalarda da önemli bir yol göstericidir (Kocaman, 2014, s. 271).

Cumhuriyet Döneminde ülkemizin birçok ilinin idari sınırlarında bir değişiklik olmamıştır. Ancak ekonomik yapıda ve ulaşım şartlarında meydana gelen değişiklikler nedeniyle il merkezlerinin etki sahalarında gelişmeler yaşanmıştır. Nitekim bazı illerin idari sınırları içerisinde kalan kimi ilçeler bağlı bulunduğu il merkezi yerine komşu il merkezinin etki sahasına girmiştir. Yine benzer durum ilçe içerisinde yer alan bazı köyler için de söylenebilir. $\mathrm{Bu}$ tür yerleşmeler ilçe merkezi veya il merkezi ile olan ilişkilerini resmi işler ile sınırlandırmışlardır. Ortaya çıkan bu durum insanların bir tercihi olmaktan öte coğrafi faktörlerin yarattığı bir zorunluluktur (Koca, Koca ve Yazıcı, 2010, s. 110).

\section{Araştırma Sahasının Konumu ve Başlıca Coğrafi Özellikleri}

Araştırma sahasını oluşturan Afyonkarahisar ili, ülkemizin batı kesiminde yer alıp topraklarının çok büyük bölümü Ege Bölgesi'nin İç Batı Anadolu Bölümü'nde yer almaktadır. İlin sahip olduğu matematik konum ise yaklaşık olarak $37^{\circ} 47^{\prime}-39^{\circ} 12^{\prime}$ kuzey paralelleri ile $29^{\circ} 50^{\prime}-31^{\circ} 38^{\prime}$ doğu meridyenleri arası şeklindedir.

Afyonkarahisar ili batıdan Uşak, kuzeybatıdan Kütahya, kuzeyden Eskişehir, doğudan Konya, güneydoğudan Isparta, güneyden Burdur ve güneybatıdan Denizli illeri ile çevrilidir (Şekil 1).

Afyonkarahisar ili idari bakımdan merkez ilçe ile birlikte toplam 18 ilçeye sahiptir. Bu ilçelerden 11 tanesi Ege Bölgesi sınırları içinde yer alırken Emirdağ ve Sultandağ ilçeleri İç Anadolu; ilin güney kesiminde yer alan Dinar, Evciler, Dazkırı, Başmakçı ve Kızılören ilçeleri Akdeniz Bölgesi sınırları içine dahil olmaktadır. 
Tablo 1. Afyonkarahisar'ın çevresindeki idari birimler

\begin{tabular}{lll}
\hline \multicolumn{1}{c}{ Coğrafi Yön } & Komşu İl İdari Birimi & \multicolumn{1}{c}{ Komşu İlçe İdari Birimi } \\
\hline Kuzey ve Kuzeydoğu & Eskişehir & Seyitgazi, Han, Çifteler ve Sivrihisar ilçeleri \\
\hline Kuzeybatı & Kütahya & Merkez, Altıntaş ve Dumlupınar ilçeleri \\
\hline Doğu & Konya & Çeltik, Yunak, Tuzlukçu ve Akşehir ilçeleri \\
\hline Güneydoğu ve Güney & Isparta & Yalvaç, Senirkent, Uluborlu ve Keçiborlu ilçeleri \\
\hline Güney & Burdur & Yeşilova ilçesi \\
\hline Güneybatı & Denizli & Çivril, Baklan, Çardak ve Bozkurt ilçeleri \\
\hline Batı & Uşak & Banaz ve Sivaslı ilçeleri \\
\hline
\end{tabular}

Şekil 1. Afyonkarahisar ilinin lokasyon haritası

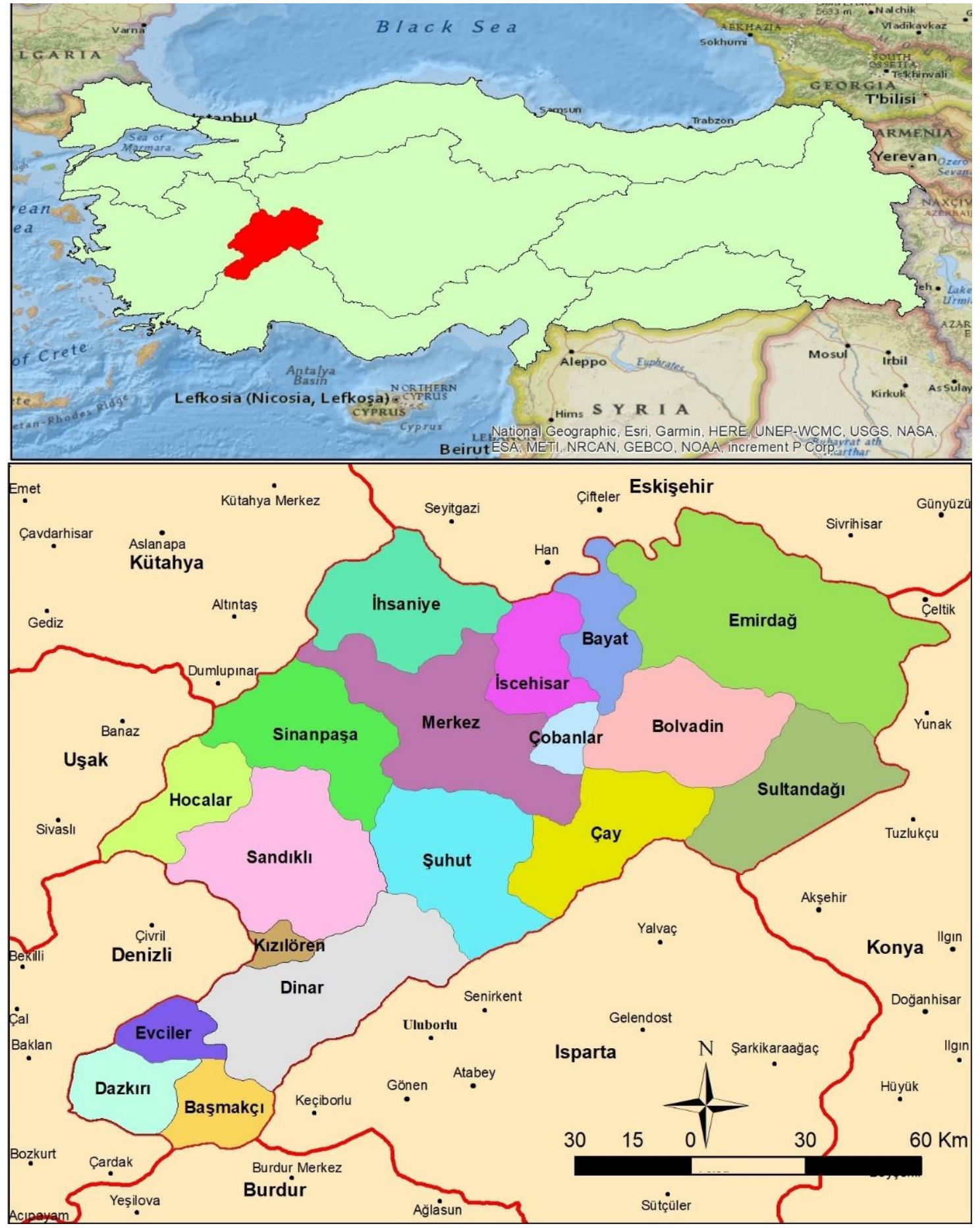


Afyonkarahisar il arazisi fiziki bakımdan dağlık alanlar, dağlık alanlar tarafindan ayrilan ovalar ve ilin özellikle kuzey ve kuzeydoğusunda yer alan platolar olmak üzere 3 kesim halinde belirgin yapı gösterir. Dağlık alanların ortalama yükselti değerleri $1600 \mathrm{~m}$ ile $2600 \mathrm{~m}$ arasında değişir (Yazıcı, Koca ve Koca, 2010, s. 112). Başlıca dağlık alanlar kuzeyde Ağın Dağı (1808 m), doğuda Emir Dağları (2307 m), ilin güneydoğu sınırında Karakuş Dağları (1846 m) ile Sultan Dağları (2592 m), güneyde Kumalar Dağı (2247 m), güneybatı sınırında Akdağ (2343 m) ve batıda Ahır Dağları $(1940$ m) şeklindedir. Dağlık alanların iç kesimlerindeyse tektonik ve karstik kökenli olaylar sonucu oluşmuş ve verimli tarım alanları olarak değerlendirilen Afyon, Şuhut, Gülova, Sandıklı ve Sincanlı ovaları yer almaktadır. Özellikle Afyon Ovası tektonik çökme ve ardından alüvyonlarla dolma sonucu oluşmuş alüvyal çöküntü ovasıdır (Uçar, 2007, s. $5)$.

Afyon ve çevresi kış aylarında Karadeniz ve Doğu Akdeniz havzalarında gelişen hava kütleleri ile Orta ve Doğu Avrupa'nın kuzeybatısında oluşan soğuk hava kütlelerinin etkisi altında kalır (Koçman, 1993, s. 3). Bunun sonucunda bölgede rüzgârlı ve soğuk hava koşulları oluşur. Diğer yandan yaz aylarında Basra Körfezi ve çevresinde oluşan tropikal hava kütleleri ile Doğu Akdeniz üzerinden gelen hava kütleleri Batı Anadolu'da ve Afyon çevresinde karşılaşarak etkisini gösterir (Yılmaz, 1999, s. 8). Çalışma sahası olan Afyonkarahisar bulunduğu konumun etkisi ve dağlık yapısına bağlı olarak karasal iklim özellikleri gösterir. Karasallığın etkisiyle yaz ve kış dönemleri ile gece ve gündüz arasındaki sıcaklık farkları fazladır.

Tablo 2. Afyonkarahisar il merkezinde ölçülen sıcaklık ve yağıș değerleri $(1929$ - 2019)

\begin{tabular}{|c|c|c|c|c|c|c|c|c|c|c|c|c|c|}
\hline Aylar & $\mathrm{O}$ & Ş & $\mathrm{M}$ & $\mathrm{N}$ & $\mathrm{M}$ & $\mathrm{H}$ & $\mathrm{T}$ & $\mathrm{A}$ & $\mathrm{E}$ & $\mathrm{E}$ & $\mathrm{K}$ & $\mathrm{A}$ & Yillık \\
\hline Ort. ${ }^{\circ} \mathrm{C}$ & 0,2 & 1,7 & 5,2 & 10,3 & 15 & 18,9 & 22,1 & 22 & 17,7 & 12,4 & 6,9 & 2,3 & 11,2 \\
\hline Yağıș (mm) & 44,6 & 39,6 & 44,7 & 45,8 & 54,9 & 40,6 & 22,4 & 13,5 & 21,5 & 35,2 & 33,6 & 47,1 & 443,5 \\
\hline
\end{tabular}

Kaynak: Meteoroloji Genel Müdürlüğü, www.mgm.gov.tr

Afyonkarahisar'ın denizden uzak iç kesimde yer alan konumu ve il genelinde ortalama yükselti değerlerinin $1000 \mathrm{~m}-1100 \mathrm{~m}$ civarlarında olması kış aylarının soğuk ve kar yağışı geçmesine sebep olmaktadır. Diğer yandan yaz ayları ise karasallığa bağlı olarak sıcak ve kurak özellik gösterir. Afyonkarahisar il merkezine ait uzun dönemli (1929 - 2019) meteorolojik verilere göre sıcaklık ortalamaları kış aylarında $1,4{ }^{\circ} \mathrm{C}$ olurken yaz aylarında ise $21^{\circ} \mathrm{C}$ civarındadır. Yıllık sıcaklık ortalaması ise $11,2^{\circ} \mathrm{C}$ 'dir. Aylık bazda ölçülen yağış değerleri ile yağışın yıl içindeki dağılışına bakıldığında ise en fazla yağışın $145,4 \mathrm{~mm}$ ile ilkbahar aylarında ve en düşük miktarda yağışın ise $76,5 \mathrm{~mm}$ ile yaz aylarında düştüğü görülmektedir. İl genelinde kış mevsiminin genel olarak kar yağışlı geçmesi bölgenin sahip olduğu karasallık ve yükseltinin sonucudur. İl merkezinde ölçülen $443,5 \mathrm{~mm}$ yıllık toplam yağış miktarının ise oldukça düşük olduğu görülmektedir.

İl genelinde ilçelerde yer alan meteoroloji gözlem istasyonlarının uzun dönem itibariyle verileri incelendiğinde aylık ve yıllık ortalama sıcaklık değerlerinin yükselti değerlerine bağlı olarak değiş̧iklik gösterdiği görülür. Buna göre ilin güneyinde yer alan Başmakçı $(865 \mathrm{~m})$, Dinar $(864 \mathrm{~m})$, Dazkırı $(900 \mathrm{~m})$ ve Evciler $(903 \mathrm{~m})$ ilçelerinde yıllık ortalama sıcaklık değerleri $12,9^{\circ} \mathrm{C}$ ile $13,9^{\circ} \mathrm{C}$ arasında değişmektedir. Yükseltinin artış gösterdiği ilin orta ve kuzey kesimlerindeki Şuhut $(1140 \mathrm{~m})$, Sinanpaşa $(1164 \mathrm{~m})$, Hocalar $(1130 \mathrm{~m})$, Bayat $(1100 \mathrm{~m})$ ilçelerinde ise yıllık ortalama sıcaklıklar bir miktar düşüş göstererek $11,0^{\circ} \mathrm{C}-11,5^{\circ} \mathrm{C}$ arasında gerçekleşmektedir. İklimi yansıtan bir diğer ölçüt olan yağış verilerine baktığımızda ise daha düzensiz bir dağılım görülmektedir. Bu anlamda ilçelerde gerçekleşen yıllık yağış toplamı $346 \mathrm{~mm}$ (Evciler) ile 563 mm (Kızılören) değerleri arasındadır.

\section{Veri Kaynakları Amaç ve Yöntem}

Afyonkarahisar ilinin idari coğrafya analizini yapmaya çalıştığımız bu araştırmada ilk olarak idari coğrafya kavramı üzerinde durularak bu kavramın Türkiye'deki idari yapılanma 
üzerindeki etkileri vurgulanmıştır. Bu kavram açıklanırken idari coğrafya alanında daha önce yapılmış çalışmalardan alıntılar yapılmıştır.

Çalışmanın sonraki bölümünde Afyonkarahisar'ın idari bakımdan geçirdiği aşamalar Selçuklu Dönemi’nden başlamak üzere günümüze değin özetlenmiştir. Bu özetleme yapılırken tarih biliminin bakış açısı ve verilerinden faydalanılmıştır. Cumhuriyet Dönemi'ndeki idari gelişim süreci ve ilçelerin idari yapısı, kuruluş süreci ile ilgili bilgiler İçişleri Bakanlığı İller İdaresi Genel Müdürlügü̈ne ait internet sitesi üzerinden ve Resmi Gazete'nin ilgili sayılarından derlenmiştir.

Araştırma sahasının fiziki ve beşeri özelliklerine ait veriler ilgili kamu kurumlarından temin edilmiştir. Bu kapsamda Harita Genel Komutanlığ 1 , Devlet Meteoroloji İşleri Genel Müdürlügü verilerine müracaat edilmiştir. Diğer yandan nüfus verileri Türkiye İstatistik Kurumu'nun (TÜİK) Adrese Dayalı Nüfus Kayıt Sistemi'nden (ADNKS) temin edilmiştir.

Afyonkarahisar'ın idari coğrafyasına ait değerlendirmeler yapılırken ilçe merkezlerinin Afyonkarahisar il merkezine, belde yerleşmelerinin ise bağlı bulundukları ilçenin merkezi ve Afyonkarahisar il merkezine olan uzaklıklarına yer verilmiştir. Aynı zamanda bu belirtilen idari yerleşme türlerinin en yakın farklı bir idari merkeze olan uzaklıkları da hesaplanarak tablolar halinde sunulmuştur. Bu uzaklık hesaplaması Coğrafi Bilgi Sistemleri (CBS) yöntemi ile yapılmıştır. Uzaklık hesaplaması ile ulaşmak istediğimiz nokta yerleşmelerin daha büyük hangi idari merkezin etki sahasında kaldıklarına yönelik değerlendirmeye dayanmaktadır.

\section{Afyonkarahisar İlinin İdari Gelişimi}

Osmanlı idari teşkilat yapısını incelediğimizde en büyük idari birim ilk dönemlerde "Beylerbeyliği”, 16. yy sonlarından itibaren ise "Eyalet" olarak isimlendirilmekteydi. Fetih politikalarına bağlı olarak Anadolu ve Rumeli'de topraklarını genişleten Osmanlı Devleti, idaresi altındaki bölgenin yönetimini kolaylaştırmak adına ülkeyi eyaletlere ayırmıştır. Zamanla eyalet sayısı toprakların büyümesine bağlı olarak artış göstermiş̧ir. Öyle ki 17. yy. başında eyalet sayısı 32'ye yükselmiştir. Eyalet birimi ise kendisine bağlı sancak veya liva adı verilen idari birimlerden oluşmaktadır. Sancak Osmanlı idari sisteminde en temel yönetim birimidir (İnalc1k, 1995:548-550).

1864 yılında yapılan vilayet düzenlemesi değişikliğiyle taşra yönetimi; vilayet, sancak, kaza ve köy şeklinde düzenlenmiştir. Böylece vilayet yöneticisi vali unvanı alırken sancak yöneticisi mutasarrıf ve kaza yöneticisi kaymakam olarak adlandırılmıştır. Sonraları köylerin bir araya getirilmesiyle oluşturulan nahiye biriminin başına da nahiye müdürü atanmıştır (Solak, 2012:77-78).

Afyonkarahisar'ın bulunduğu bölge XIII. yüzyıl başlarında Bizans elinden alınıp ilk olarak Anadolu Selçuklu Devleti'nin eline geçmiştir. Anadolu Selçuklu Devleti'nin yıkılmasıyla birlikte Afyonkarahisar, Sahipata Oğulları Beyliği’nin merkezi olmuştur. Bu dönemde "Karahisar-1 Sahib" olarak anılan bu bölge bir müddet Germiyanoğulları Beyliği'nin idaresinde kaldıktan sonra 1428 yılından itibaren Yıldırım Bayezid döneminde Osmanlı hakimiyetine girmiştir (Şahin, 2002, s. 40).

Afyonkarahisar, Osmanlı idaresine girdikten sonra sancak haline getirilerek Anadolu Eyaleti'ne bağlanmıştır. Osmanlı Dönemi'nde bölgenin adı tahrir defterlerinde "Karahisar-1 Sahip" veya "Karahisar Sancağı" olarak kayıt altına alınmıştır (Emecen ve Şahin, 1999, s. 66). II. Bayezid Dönemi'nde hazırlanan tahrir defterlerine bakıldığında Karahisar'ın idari taksimatında Karahisar, Barçınlı, Bolvadin, Çola, Şuhut, Oynaş ve Sandıklı olmak üzere 7 tane kaza olduğu görülmüştür (Karazeybek, 2004, s. 76). Bu idari taksimat zaman zaman küçük değişikliklere uğrasa da genel olarak ana yapısını muhafaza etmiştir. 
Tablo 3. 1831 y1lında Anadolu eyaletinde bulunan sancaklar

\begin{tabular}{cc}
\hline Eyalet & \multicolumn{1}{c}{ Sancaklar } \\
\hline \multirow{2}{*}{ Anadolu } & $\begin{array}{l}\text { Kütahya, Hüdavendigar, Karahisar-ı Sahip, Sultan Önü, Ankara, Çankırı, Bolu, Kastamonu, } \\
\text { Aydın, Saruhan, Menteşe, Hamit İli, Teke İli, Karesi, Viranşehir. }\end{array}$ \\
\hline
\end{tabular}
Kaynak: akt. Satıc1, 2008:1 (Baykara, 1988, s. 116).

1836 yılında II. Mahmut Dönemi’nde yapılan idari düzenlemeyle birlikte merkezi Bursa olan Hüdavendigar Eyaleti kurulmuş ve Karahisar-1 Sahip, kurulan bu eyalette sancak olarak yer almıştır (Satıc1, 2008:16-17). Karahisar-1 Sahip Sancağ1, Hüdavendigar Eyaletine dahil olduktan sonra yeni kazaların da idari bakımdan kendisine katılmasıyla sınırlarında bir genişleme olmuştur. Bu genişleme sonucunda 10 olan kaza sayısı 19'a yükselmiştir (Karazeybek, 2004, s. $80)$.

Tablo 4. 1863 - 1864 Senesinde Hüdavendigar Eyaletinde bulunan sancaklar

\begin{tabular}{cc} 
Eyalet & Bağlı Sancaklar \\
\hline Hüdavendigar & Merkez Bursa, Kocaeli, Kütahya, Karahisar-1 Sahip, Karesi, Biga, Erdek, Ayvalık. \\
\hline
\end{tabular}

$$
\text { Kaynak: Satıc1, 2008, s. 427-428 }
$$

XIX. yy. sonlarına gelindiğinde Afyonkarahisar Sancağı'nın idari yapısı Karahisar, Şuhut, Bolvadin, Çal, Sandıklı ve Aziziye (Barçınlı) kazalarından oluşurken çeşitli zamanlarda bazı nahiye ve kazaların statülerinde bir takım değişiklikler gerçekleşmiştir. Osmanlı Devleti'nin son döneminde mevcut olan bu idari yapı Cumhuriyet Dönemi idari yapısının da temelini oluşturmuştur (Daşdemir, 2004, s. 138).

Tablo 5. Afyonkarahisar ilinde Cumhuriyet Dönemi'nde yapılan idari düzenlemeler

\begin{tabular}{|c|c|c|}
\hline Kuruluş Tarihi & İlçeler & Açıklama \\
\hline $\begin{array}{l}\text { Cumhuriyet } \\
\text { Öncesi Dönem }\end{array}$ & $\begin{array}{l}\text { Merkez, Bolvadin, } \\
\text { Dinar, Emirdağ ve } \\
\text { Sandıklı }\end{array}$ & $\begin{array}{l}\text { 20.04.1924 tarih ve } 491 \text { sayılı Teşkilatı Esasiye Kanunu } \\
\text { düzenlemesiyle Afyonkarahisar vilayeti kurulmuştur. }\end{array}$ \\
\hline 1.04 .1946 & Şuhut & $\begin{array}{l}\text { 20.02.1946 tarih ve } 6237 \text { sayılı Resmi Gazetede yayımlanan } \\
4869 \text { sayılı Kanun ile Şuhut ilçesi kurulmuştur. }\end{array}$ \\
\hline 1.03 .1953 & Sinanpaşa & $\begin{array}{l}03.03 .1953 \text { tarih ve } 8349 \text { sayılı Resmi Gazetede yayımlanan } \\
6068 \text { sayılı kanun ile Sinanpaşa ilçesi kurulmuştur. }\end{array}$ \\
\hline 1.04 .1958 & Çay ve Sultandağ & $\begin{array}{l}\text { 27.06.1957 tarih ve } 9644 \text { sayılı Resmi Gazetede yayımlanan } \\
7033 \text { sayılı kanun ile Çay ve Sultandağı ilçeleri } \\
\text { kurulmuştur. }\end{array}$ \\
\hline 1.04 .1959 & Dazkırı ve İhsaniye & $\begin{array}{l}\text { 27.06.1957 tarih ve } 9644 \text { sayıl Resmi Gazetede yayımlanan } \\
7033 \text { sayılı kanun ile Dazkırı ve İhsaniye ilçeleri } \\
\text { kurulmuştur. }\end{array}$ \\
\hline 4.07.1987 & $\begin{array}{l}\text { Başmakçı, Bayat ve } \\
\text { İşcehisar }\end{array}$ & $\begin{array}{lccccc}04.07 .1987 & \text { tarih } & \text { ve } 19507 & \text { sayılı Resmi } & \text { Gazetede } \\
\text { yayımlanan } & 3392 & \text { sayılı kanun } & \text { ile Başmakçı, Bayat ve } \\
\text { İşcehisar ilçeleri kurulmuştur. } & & & \\
\end{array}$ \\
\hline 20.05 .1990 & $\begin{array}{l}\text { Çobanlar, Evciler, } \\
\text { Hocalar ve Kizılören }\end{array}$ & $\begin{array}{l}20.05 .1990 \text { tarih ve } 20523 \text { sayılı Resmi Gazetede } \\
\text { yayımlanan } 3644 \text { sayıll kanun ile Çobanlar, Evciler, Hocalar } \\
\text { ve Kızılören ilçeleri kurulmuştur. }\end{array}$ \\
\hline
\end{tabular}

Kaynak: İçişleri Bakanlığı İller İdaresi Genel Müdürlüğü

Cumhuriyet'in ilk döneminde 1923-1928 y1lları arasında ülkenin idari yapısında köklü değişiklikler yapılmıştır. 20.04.1924 tarih ve 491 sayılı "Teşkilat-1 Esasiye Kanunu" düzenlemesi ile yapılan değişiklikle Osmanlı'dan kalan sancak sistemi tamamen kaldırılarak "vilayet teşkilatı" kurulmuştur (Karagel, Üçeçam Karagel, 2014, s. 18-19). Kurulan bu yeni idari sisteme göre vilayetler kazalara, kazalar nahiyelere ve nahiyeler de köylere ayrılmıştır. Düzenlemeyle birlikte Karahisar-1 Sahip Sancağı "Afyonkarahisar" adını alarak Türkiye Cumhuriyeti'nin vilayeti olmuştur.

İlk olarak Merkez, Emirdağ, Bolvadin, Dinar ve Sandıklı olmak üzere 5 ilçeden oluşan ilde ayrıca 12 bucak ve 482 köy idari bakımdan yer almaktaydı. Sonraki yıllarda Şuhut (1946), 
Sincanlı (1953), Çay (1958), Sultandağı (1958), İhsaniye (1959) ve Dazkırı (1959) bucaklarının kaza (ilçe) olmasıyla 1971 yılı itibariyle Afyonkarahisar idari sınırları içerisinde 11 ilçe, 39 bucak ve 490 köy mevcut olmuştur (Daşdemir ve Uyan, 2001, s. 211,215).

Değişik zamanlarda idari yapıda yapılan değişikliklerle mevcut ilçelere yenileri katılmıştır. Bunlar; Bayat (1987), Başmakçı (1987), Hocalar (1990), Kızılören (1990), İşcehisar (1990), Çobanlar (1991) ve Evciler (1991) ilçeleridir (Tablo 5).

\section{Afyon İlinin İdari Coğrafya Yapısı}

Türkiye'nin mevcut mülki idari bölünüş yapısına göre en büyük idari birimi iller oluşturmaktadır. Birden fazla ilçenin bir araya gelmesiyle oluşturulan iller valilikler ve bu makama bağlı kadrolar tarafindan yönetilir. İlleri oluşturan ilçeler ise köy idari alanları ile belediye örgütlü yerleşmelerin idari alanları ve bu alanların dışında kalan hazine arazilerinden oluşmaktadır (Koday ve Erhan, 2008, s. 237).

Afyonkarahisar, $14.016 \mathrm{~km}^{2}$ lik geniş yüzölçümüyle ülkemizin 13. büyük ili olmakla birlikte kapladığ 1 alan ülke yüzölçümünün \%1,8'ini oluşturmaktadır (HGM). Bulunduğu konum itibariyle Akdeniz, Ege ve İç Anadolu Bölgeleri arasında önemli bir geçiş bölgesini oluşturur. Merkezi Ege Bölgesi'nde yer alan 8 il içerisinde en büyük yüzölçüme sahip olan Afyonkarahisar ili güneyde Akdeniz Bölgesi'nden, doğu ve kuzey yönünden ise İç Anadolu Bölgesi'nden olmak üzere idari bakımdan 7 farklı ile komşudur. Afyonkarahisar'ı idari bakımdan komşu olduğu bu yedi il ile nüfus, nüfus yoğunluğu ve yüzölçüm bakımından kıyasladığımızda ortaya çıkan veriler Tablo 6' da gösterilmiştir.

Tablo 6. Afyonkarahisar ve komşu illere ait nüfus ve yüzölçüm verileri ile ülke içindeki siralamaları

\begin{tabular}{|c|c|c|c|c|c|c|}
\hline İller & Yüzölçümü & $\begin{array}{c}\text { Ülke } \\
\text { Stralamas1 } \\
\end{array}$ & $\begin{array}{l}\text { Nüfus } \\
\text { Miktar1 }\end{array}$ & $\begin{array}{c}\text { Ülke } \\
\text { Stralamas1 } \\
\end{array}$ & $\begin{array}{c}\text { Nüfus } \\
\text { Yoğunluğu }\end{array}$ & $\begin{array}{c}\text { Ülke } \\
\text { Siralamas1 } \\
\end{array}$ \\
\hline Konya & 40.838 & 1 & 2.250 .020 & 7 & 55,1 & 51 \\
\hline Afyonkarahisar & 14.016 & 13 & 736.912 & 31 & 52,6 & 54 \\
\hline Eskişehir & 13.960 & 14 & 888.828 & 25 & 63,7 & 40 \\
\hline Denizli & 12.134 & 22 & 1.040 .915 & 23 & 85,8 & 29 \\
\hline Kütahya & 11.634 & 25 & 576.688 & 38 & 49,6 & 57 \\
\hline Isparta & 8.946 & 33 & 440.304 & 45 & 49,2 & 58 \\
\hline Burdur & 7.175 & 47 & 267.092 & 66 & 37,2 & 66 \\
\hline Uşak & 5.555 & 61 & 369.433 & 52 & 66,5 & 36 \\
\hline
\end{tabular}

Tablo 6'ya göre Afyonkarahisar, çevresindeki komşu illere göre yüzölçüm bakımından Konya'dan sonra ikinci sırada gelirken sahip olduğu bu geniş yüzölçüm ile ülke içinde 13 . sırada yer alır. 2020 yılı itibariyle 736.912 kişilik nüfusuyla ülkenin 31. kalabalık ili olan Afyonkarahisar, Konya (2.250.020), Denizli (1.040.915) ve Eskişehir (888.828) illerinin ardından dördüncü sırada gelmektedir.

Kapladığı geniş alanın etkisine bağlı olarak Afyonkarahisar $52,6 \mathrm{kişi} / \mathrm{km}^{2}$ nüfus yoğunluğuyla Türkiye ortalaması olan $107 \mathrm{kişi} / \mathrm{km}^{2}$ yoğunluğun oldukça altında kalarak ülke içinde 54. sırada gelir. Komşu iller arasındaki yeri ise Denizli $\left(85,8 \mathrm{kişi} / \mathrm{km}^{2}\right)$, Uşak $(66,5$ kişi $\left./ \mathrm{km}^{2}\right)$, Eskişehir $\left(63,7 \mathrm{kişi} / \mathrm{km}^{2}\right)$ ve Konya $\left(55,1 \mathrm{kişi} / \mathrm{km}^{2}\right)$ illerinden sonra beşinci sıradır.

İdari bakımdan sınırları içerisinde merkez ilçe ile birlikte toplam 18 ilçe barındıran Afyonkarahisar' da engebeli yapıya bağlı olarak ilçe yüzölçümleri arasında büyük dengesizlikler vardır. İlin en geniş yüzölçüme sahip ilçeleri sırasıyla Emirdağ $\left(2.103 \mathrm{~km}^{2}\right)$, Merkez $(1.261$ $\left.\mathrm{km}^{2}\right)$ ve Dinar $\left(1.254 \mathrm{~km}^{2}\right)$ ilçeleri olurken Kızılören $\left(111 \mathrm{~km}^{2}\right)$, Çobanlar $\left(165 \mathrm{~km}^{2}\right)$ ve Evciler $\left(252 \mathrm{~km}^{2}\right)$ ilçeleri ise yüzölçümün en küçük olduğu ilçelerdir (Tablo 7). 
Şekil 2. Afyonkarahisar ilçelerinin nüfus dağılış haritası

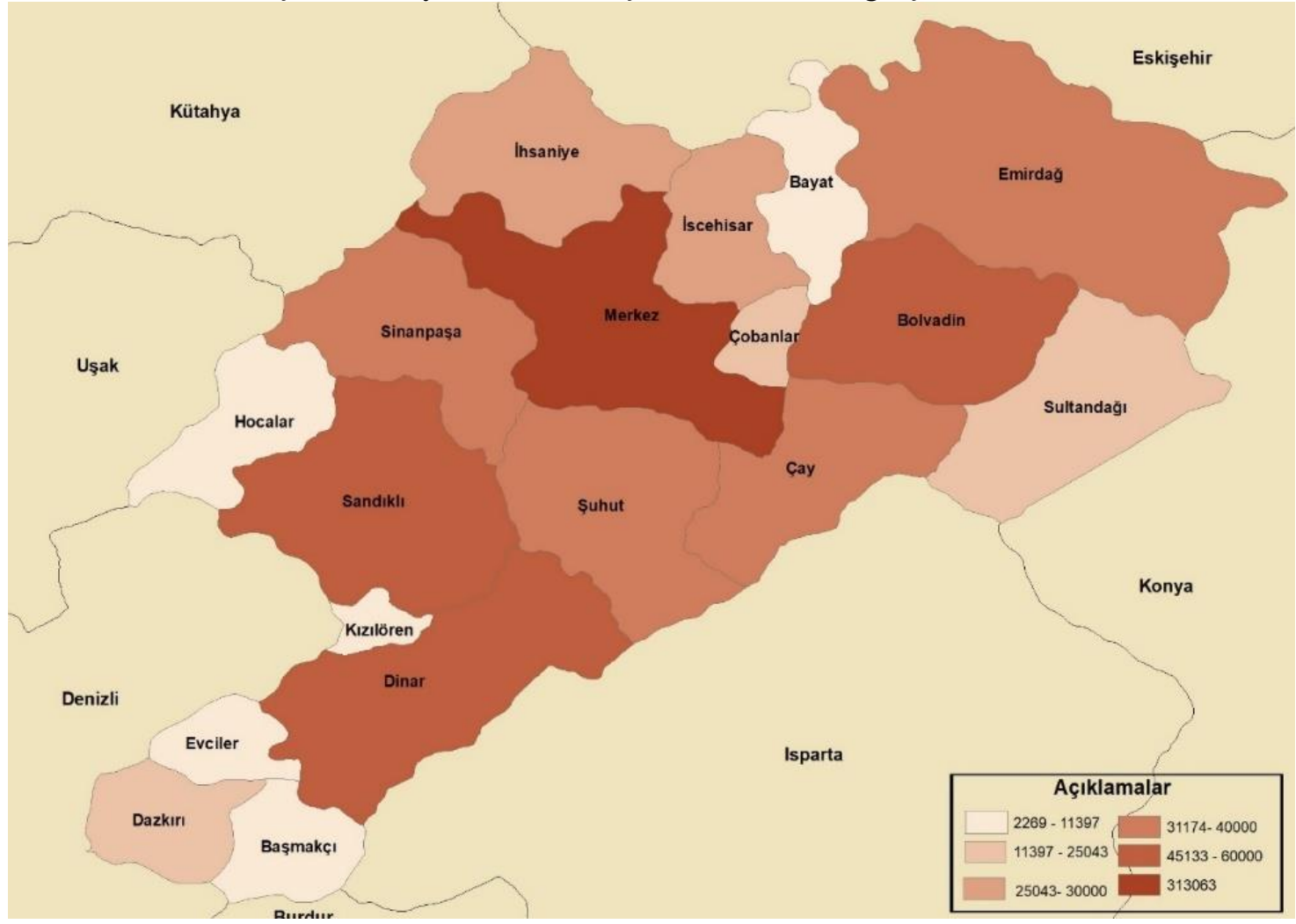

Ülke çapına yayılmış değişik türde ve fonksiyondaki yerleşmeler yakın çevresindeki ekonomik faaliyet sahalarıyla birlikte ele alınarak sınırlandırılır ve mülki idari bölünme gerçekleşir. Bu bölünme sonucunda köy ve kent idari alanları meydana gelir (Özçağlar, 2005, s. 5). Afyonkarahisar arazilerinin geniş ve yer şekillerinin parçalı yapısı nedeniyle ilçe, belde ve köy gibi alt idari birim sayısı fazladır. Dağlık alanlar arasında yer alan havzalarda kendi içerisinde bütünlük oluşturacak şekilde Sandıklı, Emirdağ ve Dinar gibi orta büyüklükte şsehirler ve bu şehirlere bağlı kasaba ve köyler oluşmuştur (Koca, Koca ve Yazıc1, 2010, s. 118).

İdari coğrafya kapsamında yapılan çalışmalarda bir idari birimin incelemesi kırsal idari alanlar ve kentsel idari alanlar olmak üzere ayrı şekilde incelenir. Çalışmamızın bu bölümünde araştırma sahası idari coğrafya prensiplerine uygun olarak kentsel idari alanlar ve kırsal idari alanlar olmak üzere ayrı şekilde incelenecektir.

Tablo 7 incelendiğinde ilçeler arasında yüzölçümleri bakımından görülen büyük farklılıklarla birlikte benzer durum ilçe nüfus miktarları için de söylenebilir. Sosyal ve ekonomik anlamda birçok imkânı barındıran ve il toplam nüfusunun \%42,5'ini toplayan merkez ilçe 313.063 kişilik nüfusu ve $248,3 \mathrm{kişi} / \mathrm{km}^{2}$ yoğunluğu ile en hareketli idari birimdir. Merkez ilçenin ardından Sandıklı (55.252), Dinar (47.516) ve Bolvadin (45.133) ilçeleri nüfus miktarı bakımından diğer büyük ilçelerdir. Tablonun son sıralarında ise düşük nüfus miktarı ve nüfus yoğunluklarıyla özellikle 1987 yılı ve sonrasında ilçe statüsü kazanan Bayat (7.573), Evciler (7.311) ve Kızılören (2.269) ilçelerinin yer aldığı görülmektedir. 
Tablo 7. Afyonkarahisar iline ait ilçelerin nüfus ve yüzölçüm verileri

\begin{tabular}{|c|c|c|c|c|c|c|c|c|c|}
\hline İlçe Ad 1 & $\begin{array}{l}\text { Toplam } \\
\text { Nüfus }\end{array}$ & $\%$ 'si & $\begin{array}{l}\text { Yüzölçüm } \\
\left(\mathrm{Km}^{2}\right)\end{array}$ & $\begin{array}{c}\text { Yoğ. } \\
\text { Kişi//Km² }\end{array}$ & İlçe Ad1 & $\begin{array}{l}\text { Toplam } \\
\text { Nüfus }\end{array}$ & $\%$ 'si & $\begin{array}{l}\text { Yüzölçüm } \\
\left(\mathrm{Km}^{2}\right)\end{array}$ & $\begin{array}{c}\text { Yoğ. } \\
\text { Kişi/Km } \\
2\end{array}$ \\
\hline Merkez & 313.063 & 42,5 & 1.261 & 248,3 & Sultandağ 1 & 14.517 & 2,0 & 928 & 15,6 \\
\hline Sandıklı & 55.252 & 7,5 & 1.238 & 44,6 & Çobanlar & 14.355 & 1,9 & 165 & 87,0 \\
\hline Dinar & 47.516 & 6,4 & 1.254 & 37,9 & Dazkırı & 11.397 & 1,5 & 408 & 27,9 \\
\hline Bolvadin & 45.133 & 6,1 & 944 & 47,8 & Başmakçı & 9.617 & 1,3 & 361 & 26,6 \\
\hline Sinanpaşa & 39.432 & 5,4 & 889 & 44,4 & Hocalar & 9.245 & 1,3 & 506 & 18,3 \\
\hline Emirdă̆ & 39.518 & 5,4 & 2.103 & 18,8 & Bayat & 7.573 & 1,0 & 411 & 18,4 \\
\hline Suhut & 36.690 & 5,0 & 1.044 & 35,1 & Evciler & 7.311 & 1,0 & 252 & 29,0 \\
\hline Çay & 31.174 & $\overline{4,2}$ & 803 & 38,8 & Kızılören & 2.269 & 0,3 & 111 & 20,4 \\
\hline İhsaniye & 27.807 & 3,8 & 849 & 32,8 & & & & & \\
\hline İşcehisar & 25.043 & 3,4 & 489 & 51,2 & & 736.912 & 100,0 & 14.016 & 52,6 \\
\hline
\end{tabular}

\section{Kentsel İdari Alanlar}

“Kent” sözcüğü günümüz Türkiye'sinde genel olarak şehir kelimesinin karş1lığ1 ve eş anlamı olarak kullanılan sözcüktür. İki kavram arasında bir takım farklar olmasına rağmen idari bakımdan ülkemizdeki kasaba ve şehirler genelleştirme yapılarak "kentsel yerleşmeler" başlı̆̆ altında toplanır. Diğer yandan belediye teşkilatına sahip olan ilçe merkezleri, il merkezleri ile belediye örgütüne sahip belde yerleșmelerinin içerisinde yer alan idari alanlara "kentsel idari alan" denilmektedir (Özçağlar, 2005, s. 9). Türkiye'de 2020 yılı itibariyle belediye teşkilatının kurulduğu 51 il merkezi, 922 ilçe merkezi ve 386 belde merkezi olmak üzere toplam 1.389 adet kentsel idari alan bulunmaktadır (İçişleri Bakanlığı İller İdaresi Genel Müdürlüğü, 2021).

5393 Say1lı Belediye Kanunu'na göre nüfusu 5.000 ve üzerindeki yerleşmelerde belediye örgütü kurulabilirken ilçe ve il merkezlerinde belediye kurulması ise zorunludur. Yine aynı kanunun diğer maddelerine göre belediye sınırları çizilirken eskiden beri o yerleşim yerine ait sayılan tarla, bağ, bahçe, çayır, mera, otlak, yaylak, zeytinlik gibi yerler belediye sınırları içerisine alınır. Belediye sınırları dere, tepe, yol gibi sabit noktalardan geçirilir (Resmi Gazete, 2005, Sayı:25874). Burada da görüldüğü gibi belediye örgütünün kurulduğu ve idari coğrafyada kentsel idari alan olarak tanımlanan bölgeler sadece yerleşim yapılan bölge ile sınırlı değildir. Yerleşim alanı dışında kalan bu bölgeler mücavir alan olarak tanımlanır ve belediyelerin sorumluluk alanındadır. Bu durum Resmi Gazete'nin 09.05.1985 tarih ve 18749 sayılı basımında yer alan İmar Kanunu'nun 5. maddesinde belirtilmiştir. Buradan hareketle kentsel idari alanın sadece yerleşim alanı olmakla kalmayıp belediye sınırlarının tamamını kapsadığını belirtebiliriz.

Belediye örgütüne sahip olan ve kentsel idari alan olarak tanımlanan yerleşim yerlerinde en küçük idari birim mahalledir. 5393 sayılı Belediye Kanunu'nun 3. maddesinde "Belediye sınırları içinde, ihtiyaç ve özellikleri benzer özellikler gösteren ve sakinleri arasında komşuluk ilişkisi bulunan idari birim" olarak tanımlanan mahallelerde yaşayan nüfus kentli nüfus olarak tanımlanır. Yine aynı kanunun 9. maddesine göre muhtar ve ihtiyar heyeti tarafından yönetilen mahallelerin idari sınırları bağlı bulunduğu belediye tarafından belirlenir Resmi Gazete, 2005, Say1:25874).

Afyonkarahisar ilinde kentsel idari alan olarak nitelendirebileceğimiz yerleşme sayısı 59'dur. Bunlardan biri merkez ilçe olarak da tanımlanan il merkezi olurken 17 tanesi ilçe merkezi ve 41 tanesi ilçelere bağli belde yerleşmeleridir. Diğer yandan Afyonkarahisar'da ilçe merkezlerinde 260 mahalle ve bu ilçelere bağli beldelerde 183 mahalle olmak üzere toplam 443 mahalle yer alır. 
Tablo 8. Afyonkarahisar ilindeki ilçe merkezlerinde yaşayan nüfusu

\begin{tabular}{lccclccc}
\hline İlçe Adı & $\begin{array}{c}\text { Mahalle } \\
\text { Sayısı }\end{array}$ & $\begin{array}{c}\text { İlçe } \\
\text { Merkezi } \\
\text { Nüfusu }\end{array}$ & $\begin{array}{c}\text { İl Merkezine } \\
\text { Uzaklık (Km) }\end{array}$ & İlçe Adı & $\begin{array}{c}\text { Mahalle } \\
\text { Sayısı }\end{array}$ & $\begin{array}{c}\text { İlçe } \\
\text { Merkezi } \\
\text { Nüfusu }\end{array}$ & $\begin{array}{c}\text { İl Merkezine } \\
\text { Uzaklık (Km) }\end{array}$ \\
\hline Merkez & 59 & 245.405 & --- & Dazkırı & 6 & 5.612 & 141 \\
\hline Sandıklı & 13 & 33.496 & 62 & Sultandağ & 6 & 5.276 & 68 \\
\hline Bolvadin & 49 & 32.475 & 53 & Başmakçı & 8 & 5.034 & 130 \\
\hline Dinar & 28 & 26.122 & 107 & Bayat & 4 & 4.096 & 48 \\
\hline Emirdağ & 10 & 20.175 & 74 & İhsaniye & 8 & 3.876 & 36 \\
\hline Şuhut & 13 & 14.857 & 29 & Sinanpaşa & 8 & 3.596 & 33 \\
\hline Çay & 17 & 14.800 & 49 & Evciler & 6 & 3.451 & 134 \\
\hline İşcehisar & 11 & 13.186 & 24 & Hocalar & 3 & 2.287 & 96 \\
\hline Çobanlar & 9 & 9.266 & 24 & Kizılören & 2 & 1.442 & 87 \\
\hline
\end{tabular}

Kaynak: TÜİK ADNKS (2020), mesafe verileri CBS sistemi ile hesaplanmıştır.

Tablo 8'de Afyonkarahisar ilindeki merkez ilçe ile birlikte 18 ilçe merkezinde kentsel idari alanda yaşayanların sayısı 2020 y1lı ADNKS verilerine göre toplam 444.452 kişi olurken bu ilçelere bağl1 41 belde belediyesinde yaşayanlar ise 125.105 kişidir. İlçe merkezlerindeki mahalle yerleşmeleri ile belde belediyesi sınırlarında yaşayanların toplamı 569.557'dir. Bu nüfus aynı zamanda Afyonkarahisar'ın kentli nüfusunu oluşturmakta olup toplam il nüfusunun yaklaşık \% 77,3'üne denk gelmektedir.

Şekil 3. Afyonkarahisar ilçeleri kentsel idari alan nüfus dağılımı haritası

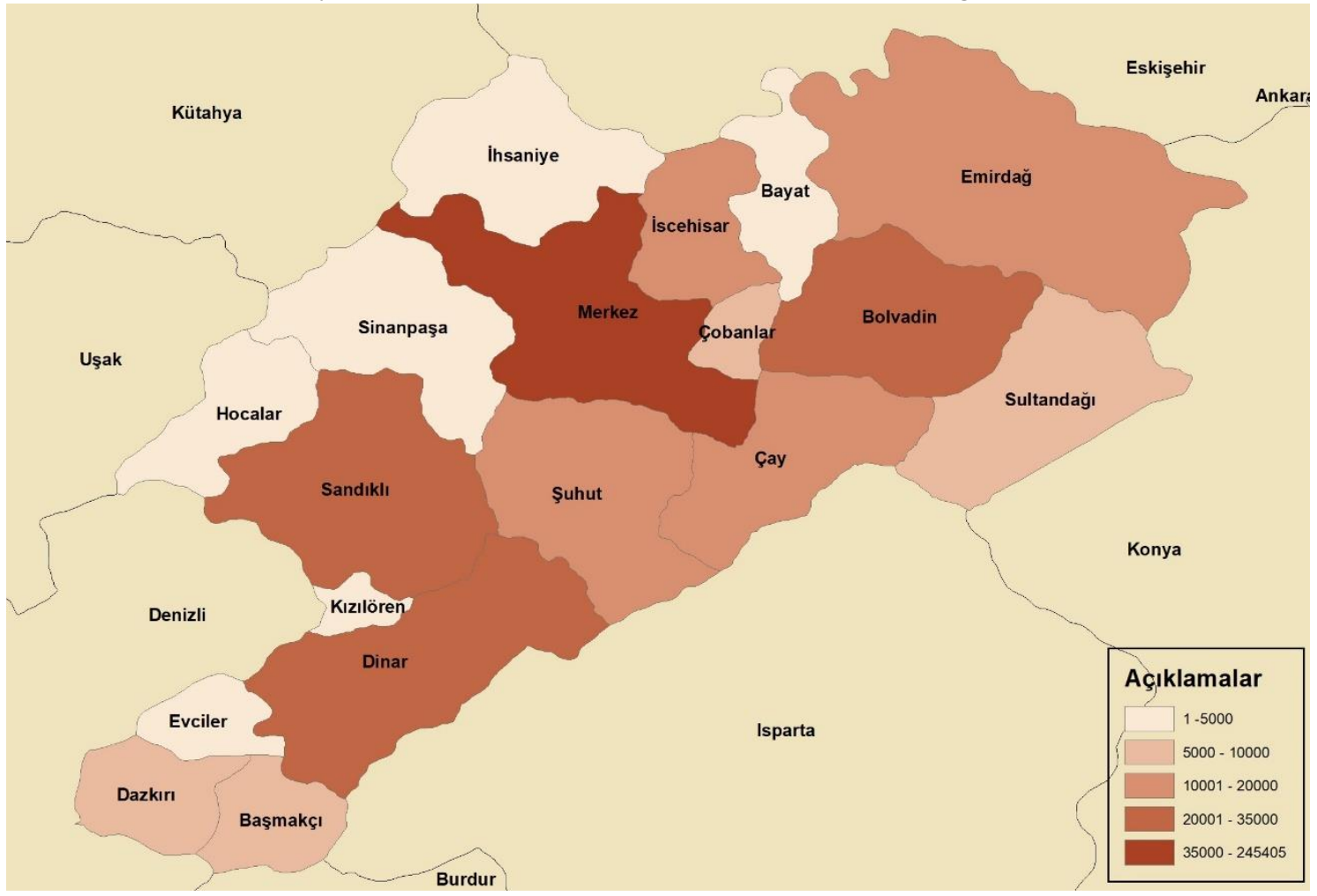

Yüzölçümün geniş olduğu ve farklı fiziki koşullara sahip olan illerde il merkezlerinin diğer ilçe merkezleri üzerindeki sosyal ve ekonomik etkileri aynı değildir. Bu anlamda il merkezinin kurulduğu sahanın konumu önem kazanmaktadır. Afyonkarahisar il merkezi, il idari sınırları içerisinde yaklaşık orta kesimde yer alır. Bu yüzden ilçe merkezlerinin il merkezine olan mesafeleri ilçeler arasında çok büyük farklar oluşturmamaktadır. İlçe merkezlerinin il merkezine olan ortalama mesafesi $70 \mathrm{~km}$ 'dir. Ancak ilin güney kısmında yer alan Dazkırı (141 km), Evciler (134 km), Başmakçı (130 km) ve Dinar (107 km) ilçelerinin il merkezine uzaklığ 1 
100 kilometrenin üstündedir. Bunlar içerisinde Dinar eski bir ilçe (Osmanlı'da kaza) yerleşmesi olarak hem nüfus hem de yüzölçüm bakımından ön plandadır. Cumhuriyet Dönemi'nde 1950'li yıllardan sonra kurulan Dazkırı, Evciler ve Başmakçı ilçeleri için Dinar önemli bir çekim sahası oluştururken Isparta il merkezine olan yakınlığı $(62 \mathrm{~km})$ ise Dinar'1 Isparta'nın etki sahasında birakmıştır.

İl merkezine mesafe (70 km'den az) ve erişim süresi (bir saatten az) bakımından yakın olan İşcehisar (24 km), Çobanlar (24 km), Şuhut (29 km), Sinanpaşa (33km), İhsaniye (36 km), Bayat $(48 \mathrm{~km})$ Çay $(49 \mathrm{~km})$, Bolvadin $(53 \mathrm{~km})$, Sandıklı $(62 \mathrm{~km})$ ve Sultandağı $(68 \mathrm{~km})$ ilçe merkezleri, Afyonkarahisar il merkezinin etki sahasında kalmaktadır. Diğer yandan bazı ilçe merkezleri komşu il merkezlerine daha yakın konumdadır. Örneğin Hocalar ilçesi Uşak il merkezine $65 \mathrm{~km}$ mesafede olurken, Dazkırı ve Evciler ilçeleri Denizli il merkezine $79 \mathrm{~km}$ ve Başmakçı ilçesi Isparta il merkezine $83 \mathrm{~km}$ mesafede yer alır. Bu ilçelerde yaşayan insanlar bazı hizmet sektörlerinde kendi yerleşim yerlerinde karşılayamadıkları ihtiyaçları için ulaşım avantajına bağlı olarak komşu il merkezlerine yönelmeyi tercih etmektedirler.

Tablo 8'deki ilçelere ait olduğu belirtilen mahalle sayıları bu ilçelerin şehirleşme durumu hakkında da ipucu vermektedir. Mahalle sayıları incelendiğinde Osmanlı'dan beri ilçe (kaza) statüsü taşıyan Dinar, Sandıklı, Emirdağ ve Bolvadin ilçelerinde mahalle sayısının ve ilçe merkezinde yaşayan kentli nüfusun fazla olduğu görülmektedir. $\mathrm{Bu}$ yerleşmelerin tarihi yapısının rolü bu durum üzerinde oldukça etkili olmuştur. Diğer yandan Tablo 8'in son kısmında mahalle sayıları ve nüfus miktarları düşük olan ilçelerin çoğu Cumhuriyet Dönemi'nde ve özellikle 1980'li yıllarla birlikte yapılan idari düzenlemelerle kurulmuştur. Bu da gösteriyor ki bir yerleşim yerinde kentsel idari alanların oluşması ve genişlemesi uzun yıllar boyu ortaya çıkan bir durumdur.

Mülki idari bölünüş içerisinde il merkezi ve ilçe merkezi görevi almamış belediye örgütlü kentsel yerleşmelere "belde" denmektedir. Kentsel idari alan olarak değerlendirilen belde belediyelerinin yönetim alanı içerisine yerleşim alanı ile birlikte tarla, bağ, bahçe, çayır, mera, otlak, yaylak, zeytinlik, kumsal ve plajlar gibi alanlar dahildir (Özçağlar, 2005, s. 13-14).

09.07.2004 tarih ve 5215 sayılı Belediye Kanunu'nun 4. Maddesi "nüfusu 5000 ve üzerinde olan yerleşim birimlerinde belediye kurulabileceğini" ifade etmektedir. Ancak ülkemizde nüfusu 5000'in altında olup belediye örgütüne sahip olan beldeler (kasaba) mevcuttur. Özçağlar'a (2005) göre bu yerleşmelerin köy idari alanları kategorisinde değerlendirilmeleri gerekir. Bu bilgiler ışığında Afyonkarahisar il sınırları içerisinde mevcut bulunan beldelere ait nüfus verilerine baktığımızda toplam 41 beldenin 39'unun nüfusunun 5000 altında kaldığı görülmektedir.

Afyonkarahisar ilinde bulunan 18 ilçeden 12 tanesinde toplam 41 belde belediyesi kurulmuştur. En fazla belde belediyesine Merkez ilçe (14) sahip olurken Başmakçı, Bayat, Dazkırı, Evciler, Hocalar ve Kızılören ilçelerinde belde belediyesi kurulmamıştır. Belde yerleşmelerinin sahip olduğu nüfus miktarlarının oldukça düşük olduğu göze çarparken belde nüfuslarının yoğun olarak 2000-3000 aralığında olduğu görülmektedir. Diğer yandan sadece nüfus kriterine bağlı olarak belde statüsünü hak eden yerleşmeler Merkez ilçeye bağlı olan Erkmen ve Işıklar kasabalarıdır.

Belde statüsüne sahip yerleşmeler diğer bir ifadeyle kasabalar, köy ve şehir yerleşmeleri arasında bir geçiş karakteri taşımaktadır. Bu bakımdan beldelerde ağırlıklı ekonomik faaliyet tarım ve hayvancilık olmakla birlikte ticaret fonksiyonunu taşıyan kasabalar da bulunmaktadır. Afyonkarahisar ilinde yer alan beldelerde en önemli ekonomik faaliyet tarım ve hayvancılıktır. 
Tablo 9. Afyonkarahisar ilinde belde belediyelerine ait veriler

\begin{tabular}{|c|c|c|c|c|c|}
\hline Bağl1 İlçe & Belde Ad 1 & Nüfus & $\begin{array}{c}\text { Mahalle } \\
\text { Sayıs1 }\end{array}$ & $\begin{array}{c}\text { İlçe } \\
\text { Merkezine } \\
\text { Uzaklık } \\
\end{array}$ & $\begin{array}{l}\text { İl Merkezine } \\
\text { Uzaklık }\end{array}$ \\
\hline \multirow{14}{*}{ Merkez } & Işıklar & 7.510 & 6 & 24 & 24 \\
\hline & Erkmen & 6.674 & 3 & 6 & 6 \\
\hline & Susuz & 4.731 & 4 & 10 & 10 \\
\hline & Salar & 4.518 & 5 & 10 & 10 \\
\hline & Çayırbağ & 4.396 & 4 & 11 & 11 \\
\hline & Sülümenli & 3.959 & 6 & 21 & 21 \\
\hline & Gebeceler & 3.507 & 5 & 22 & 22 \\
\hline & Beyyaz1 & 3.284 & 3 & 10 & 10 \\
\hline & Kocatepe & 3.175 & 2 & 13 & 13 \\
\hline & Nuribey & 3.119 & 4 & 13 & 13 \\
\hline & Sülün & 2.924 & 2 & 9 & 9 \\
\hline & Değirmenayvalı & 2.869 & 2 & 12 & 12 \\
\hline & Fethibey & 2.777 & 3 & 14 & 14 \\
\hline & Ç1krık & 2.454 & 2 & 15 & 15 \\
\hline Sand1kl1 & Akharım & 2.677 & 3 & 30 & 41 \\
\hline \multirow{2}{*}{ Bolvadin } & Dişli & 3.010 & 10 & 11 & 61 \\
\hline & Özburun & 2.060 & 5 & 16 & 56 \\
\hline \multirow{2}{*}{ Dinar } & Haydarl1 & 2.053 & 7 & 36 & 87 \\
\hline & Tatarlı & 2.933 & 6 & 41 & 76 \\
\hline \multirow{2}{*}{ Emirdağ } & Davulga & 2.385 & 6 & 23 & 98 \\
\hline & Gömü & 2.138 & 5 & 10 & 64 \\
\hline Şuhut & Karaadilli & 2.293 & 4 & 32 & 61 \\
\hline \multirow{2}{*}{ Çay } & Karamıkkaracaören & 2.520 & 4 & 12 & 48 \\
\hline & Pazarağaç & 2.603 & 5 & 11 & 44 \\
\hline İşcehisar & Seydiler & 2.165 & 2 & 9 & 32 \\
\hline Çobanlar & Kocaöz & 2.809 & 4 & 7 & 35 \\
\hline \multirow{2}{*}{ Sultandağ 1} & Dereçine & 2.020 & 5 & 8 & 75 \\
\hline & Yeşilçiftlik & 2.137 & 7 & 1 & 67 \\
\hline \multirow{4}{*}{ İhsaniye } & Döğer & 5.633 & 4 & 12 & 49 \\
\hline & Gazligöl & 2.453 & 4 & 15 & 21 \\
\hline & Kayıhan & 2.190 & 4 & 9 & 30 \\
\hline & Yaylabağ1 & 2.261 & 3 & 1 & 39 \\
\hline \multirow{9}{*}{ Sinanpaşa } & Ahmetpaşa & 2.725 & 6 & 1 & 33 \\
\hline & Akören & 3.053 & 3 & 15 & 18 \\
\hline & Düzağaç & 2.065 & 4 & 1 & 33 \\
\hline & Kılıçarslan & 2.674 & 4 & 1 & 33 \\
\hline & Kirka & 2.031 & 4 & 2 & 35 \\
\hline & Serban & 1.615 & 6 & 18 & 34 \\
\hline & Küçükhüyük & 1.949 & 5 & 6 & 26 \\
\hline & Taşoluk & 3.768 & 6 & 26 & 41 \\
\hline & Tinaztepe & 2.988 & 6 & 12 & 24 \\
\hline
\end{tabular}

Kaynak: TÜIKK ADNKS 2020 verileri

Özellikle merkez ilçe sınırları içerisinde kalan Erkmen, Işıklar, Fethibey, Çayırbağ, Susuz ve Salar ilçeleri konum olarak diğer illerle bağlantı sağlanan karayollarına yakın mevkide bulunmalarının avantajına bağlı olarak tarım ve hayvancılığa bağlı ticaret faaliyetlerinin daha 
belirgin olduğu görülmektedir. Diğer yandan İhsaniye ilçesine bağlı Döğer ile Gazligöl beldeleri turizm anlamında hareketli beldelerdir. Ayrıca Sinanpaşa ilçesine bağlı olan Serban (1615) ve Küçükhüyük (1949) beldelerinin sahip olduğu nüfus miktarları 2000 altında olduğundan mevcut belediye teşkilatlarını kaybetme ihtimali yüksektir.

Beldelerin il merkezine ortalama uzaklığ $35,4 \mathrm{~km}$ olurken bağlı bulundukları ilçe merkezlerine ortalama uzaklıkları ise 13,6 km'dir.

Şekil 4. Afyonkarahisar ilinde yer alan beldelerin dağılım haritası

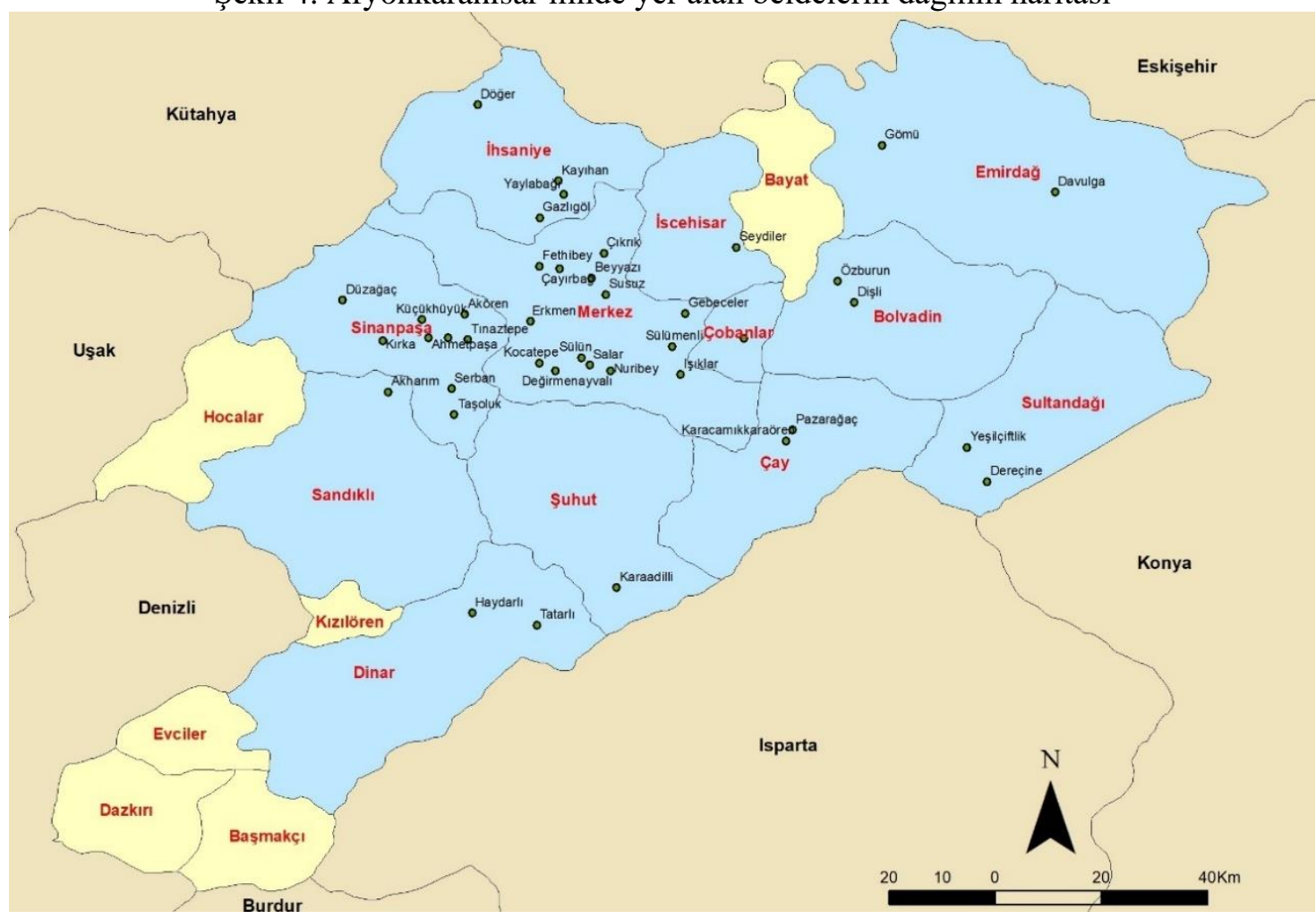

Belde belediyelerinin dağılımının gösterildiği Şekil 3'teki harita incelendiğinde beldelerin yoğun olarak il merkezini oluşturan merkez ilçe ile komşu ilçelerinde yoğunlaştı̆̆ görülmektedir. Toplam nüfusun 10.000'in altında kaldığı Dazkırı, Başmakçı, Hocalar, Bayat, Evciler ve Kızılören ilçelerinde belde belediyesi kurulmamıştır.

\section{Kursal İdari Alanlar}

Kırsal yerleşim alanlarının temel idari birimini köyler oluşturur. 1924 yılında kabul edilen Köy Kanunu'na göre; Nüfusu iki binden aşağı olan yurtlar (yerleşmeler) köy olarak kabul edilmiştir. Aynı kanunun ikinci maddesinde ise cami, mektep, otlak, yaylak, baltalık gibi ortak malları bulunan ve toplu veya dağınık olmak üzere bağ, bahçe ve tarlaları bulunan alanlar köyü teşkil ederler şeklinde tanımlanmıştır (Resmi Gazete, 1924, sayı:68). Ancak şunu da belirtmek gerekir ki 2004 yılında yürürlüğe giren 5272 sayılı Belediye Kanunu'nun 4. maddesiyle "Nüfusu 5.000 ve üzerinde olan yerleşim birimlerinde belediye kurulabilir." hükmü getirilmiştir (Resmi Gazete, 2005, sayı:2874). Buna göre köy tanımı için kullanılan 2000 nüfus kriterinin 5000 olarak kabul edilmesi durumu ortaya çıkmıştır (Özçağlar, 2005, s. 6). Ancak köy veya kent kavramı için kullanılan nüfus kriterinin tek başına yeterli olmadığı ve ülkemizde mevcut uygulamada sağlıklı bir şekilde kullanılmadığı bir gerçektir. Köy veya kent kavramı için yerleşmenin sahip olduğu fonksiyonların ve gelişmişlik düzeyinin dikkate alınması gerektiği bir gerçektir.

Afyonkarahisar ilinde 422 tane köy idari alanı yer almaktadır. Köylerin ilçelere dağılımına bakıldığında en fazla köye Emirdağ (69), Dinar (60), Sandıklı (56), ve Şuhut (36) 
ilçelerinin sahip olduğu görülürken Çobanlar (3), Kızılören (4) ve Evciler (7) ilçelerindeki köy sayısı oldukça düşüktür. Burada dikkat çeken husus ilçelerin kapladığ1 yüzölçümler ile köy sayıları arasındaki bağlantının kuvvetli olmasıdır. Zira daha önce yer verdiğimiz Tablo 7'de de görüldüğü gibi Emirdağ, Dinar, Sandıklı ve Şuhut ilçeleri Afyonkarahisar'ın fiziki ve beşeri, bakımdan en büyük ilçeleridir.

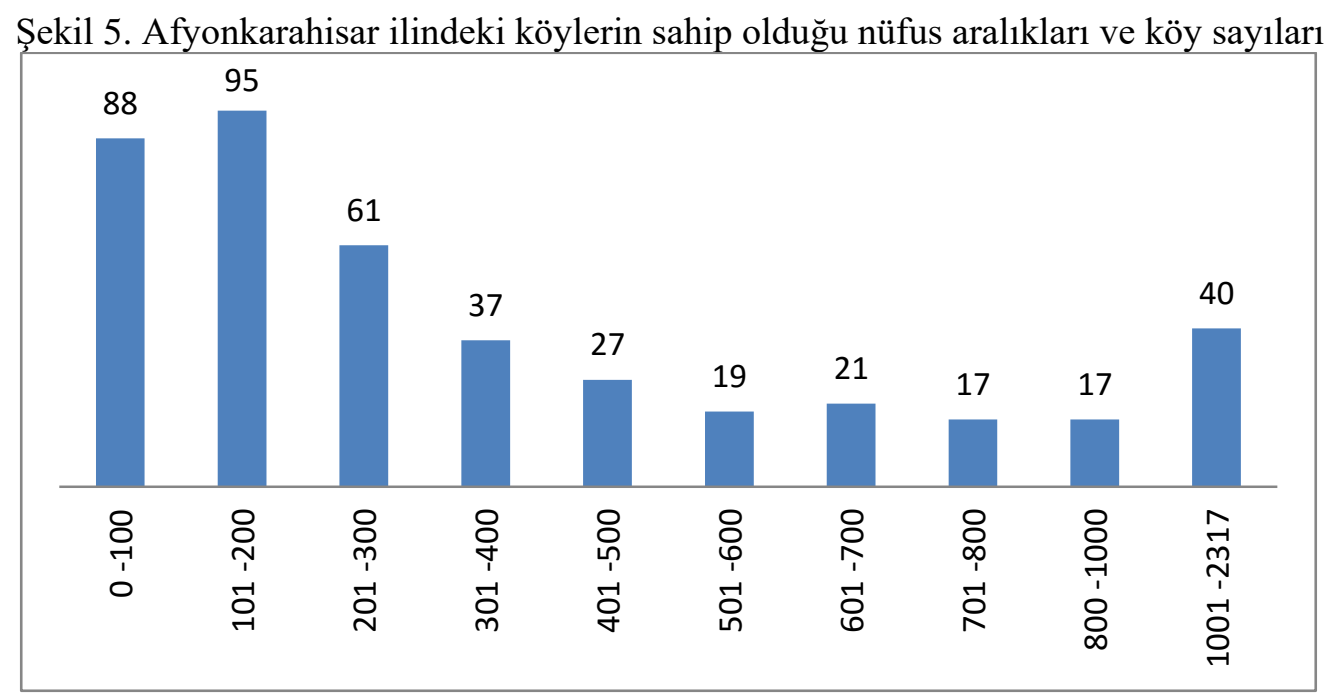

Kaynak: TÜİK (2020) ADNKS verileri

İl genelinde yer alan kırsal idari alanları oluşturan köylerde yaşayan toplam nüfus ise 2020 yılı ADNKS'ye göre 167.355 kişidir. Bu nüfus miktarı il genelindeki nüfusun \%22,7'sini oluşturmaktadır.

İldeki 422 köyün sahip olduğu ortalama nüfus miktarı 397'dir. En düşük nüfusa sahip olan köyler Sandıklı Asmacık (12), Emirdağ Leylekli (22) ve Emirdağ Avdan (23) köyleridir. Şekil 2'de yer aldığı gibi il genelinde 88 köyün nüfusu 100 ve 100'ün altında olup 95 köyün nüfusu ise 101 - 200 aralığındadır. Nüfus miktarının en fazla olduğu köylere bakıldığında ilk sıralarda İşcehisar Karağaaç (2317), Sinanpaşa Güney (2082) ve İşcehisar Çalışlar (1786) köylerinin olduğu görülmektedir (Tablo 10).

Tablo 10. Afyonkarahisar ilinin köyleri ve nüfus verileri (2020)

\begin{tabular}{|c|c|c|c|c|c|c|}
\hline İlçe & Köy & Nüfus & & İlçe & Köy & Nüfus \\
\hline Başmakçı & Akkeçili & & 607 & Bolvadin & Kurucaova & 1.062 \\
\hline Başmakçı & Akkoyunlu & & 170 & Bolvadin & Kutlu & 90 \\
\hline Başmakçı & Akpınar & & 338 & Bolvadin & Nusratl1 & 85 \\
\hline Başmakçı & Aşağıbeltarla & & 372 & Bolvadin & Ortakarabağ & 175 \\
\hline Başmakçı & Çevlik & & 84 & Bolvadin & Taşağıll & 50 \\
\hline Başmakçı & Çı̆̆r & & 608 & Bolvadin & Taşlıdere & 120 \\
\hline Başmakçı & Ekinlik & & 142 & Bolvadin & Yürükkaracaören & 280 \\
\hline Başmakçı & Hırkaköy & & 165 & Çay & Akkonak & 1.171 \\
\hline Başmakçı & Küllüce & & 197 & Çay & Armutlu & 178 \\
\hline Başmakçı & Ovacık & & 286 & Çay & Aydoğmuş & 258 \\
\hline Başmakçı & Sarı̈öy & & 231 & Çay & Bulanık & 282 \\
\hline Başmakçı & Yaka & & 607 & Çay & Cumhuriyet & 180 \\
\hline Başmakçı & Yassiören & & 334 & Çay & Çayırpınar & 427 \\
\hline Başmakçı & Yukaribeltarla & & 442 & Çay & Çayıryazı & 389 \\
\hline Bayat & Akpınar & & 161 & Çay & Deresinek & 866 \\
\hline
\end{tabular}




\begin{tabular}{|c|c|c|c|c|c|}
\hline İlçe & Köy & Nüfus & İlçe & Köy & Nüfus \\
\hline Bayat & Aşağıçaybelen & 374 & Çay & Devederesi & 374 \\
\hline Bayat & Çukurkuyu & 215 & Çay & Eber & 610 \\
\hline Bayat & Derbent & 1.063 & Çay & Göcen & 133 \\
\hline Bayat & Eskigömü & 70 & Çay & İnli & 1.556 \\
\hline Bayat & İmrallı & 717 & Çay & Kadıköy & 245 \\
\hline Bayat & İnpınar & 115 & Çay & Karamık & 863 \\
\hline Bayat & Kuzören & 54 & Çay & Kılıçkaya & 239 \\
\hline Bayat & Mallica & 119 & Çay & Koçbeyli & 1.401 \\
\hline Bayat & Muratkoru & 50 & Çay & Maltepe & 345 \\
\hline Bayat & Sağırlı & 164 & Çay & Orhaniye & 116 \\
\hline Bayat & Yukarıçaybelen & 375 & Çay & Pinarkaya & 325 \\
\hline Bolvadin & Büyükkarabağ & 1.088 & Çay & Yeşilyurt & 1.293 \\
\hline Bolvadin & Derekarabağ & 791 & Çobanlar & Akkoyunlu & 374 \\
\hline Bolvadin & Dipevler & 643 & Çobanlar & Göynük & 989 \\
\hline Bolvadin & Güney & 207 & Çobanlar & Kale & 917 \\
\hline Bolvadin & Hamidiye & 272 & Dazkırı & Akarca & 181 \\
\hline Bolvadin & Karayokuş & 977 & Dazkırı & Arıköy & 273 \\
\hline Bolvadin & Kemerkaya & 1.748 & Dazkırı & Aşağıyenice & 177 \\
\hline Dazkırı & Bozan & 430 & Dinar & Kabaklı & 73 \\
\hline Dazkırı & Çiftlik & 231 & Dinar & Kadılar & 518 \\
\hline Dazkırı & Darıcilar & 160 & Dinar & Karabedir & 158 \\
\hline Dazkırı & Hasandede & 104 & Dinar & Karahacilı & 533 \\
\hline Dazkırı & Hisaralan & 82 & Dinar & Karakuyu & 109 \\
\hline Dazkırı & İdris & 113 & Dinar & Karataş & 118 \\
\hline Dazkırı & Karaağaçkuyusu & 1.150 & Dinar & Kazanpınar & 98 \\
\hline Dazkırı & Kızı̈ören & 752 & Dinar & Keklicek & 59 \\
\hline Dazkırı & Örtülü & 27 & Dinar & Kınık & 799 \\
\hline Dazkırı & Sarıkavak & 187 & Dinar & Kizıllı & 172 \\
\hline Dazkırı & Yaylaköy & 82 & Dinar & Körpeli & 27 \\
\hline Dazkırı & Yukarıyenice & 324 & Dinar & Okçular & 310 \\
\hline Dazkırı & Yüreğil & 1.512 & Dinar & Palaz & 49 \\
\hline Dinar & Afşar & 200 & Dinar & Pinarlı & 371 \\
\hline Dinar & Akça & 210 & Dinar & Sütlaç & 302 \\
\hline Dinar & Akçin & 58 & Dinar & Tekin & 218 \\
\hline Dinar & Akgün & 451 & Dinar & Tugaylı & 55 \\
\hline Dinar & Akpınarlı & 182 & Dinar & Uluköy & 368 \\
\hline Dinar & Aktoprak & 239 & Dinar & Yaka & 88 \\
\hline Dinar & Alacatl1 & 27 & Dinar & Yapağli & 154 \\
\hline Dinar & Alparslan & 355 & Dinar & Yelalan & 149 \\
\hline Dinar & Avdan & 91 & Dinar & Yeşilçat & 284 \\
\hline Dinar & Bademli & 313 & Dinar & Yeşilhüyük & 431 \\
\hline Dinar & Bağcilar & 206 & Dinar & Yeşilyurt & 46 \\
\hline Dinar & Belenpınar & 99 & Dinar & Yiprak & 1.563 \\
\hline Dinar & Bilgiç & 46 & Dinar & Yüksel & 159 \\
\hline Dinar & Burunkaya & 152 & Emirdağ & Ablak & 85 \\
\hline
\end{tabular}




\begin{tabular}{|c|c|c|c|c|c|}
\hline İlçe & Köy & Nüfus & İlçe & Köy & Nüfus \\
\hline Dinar & Bülücalan & 287 & Emirdağ & Adayazı & 692 \\
\hline Dinar & Cerityaylası & 131 & Emirdağ & A $\breve{g}_{1} l c 1 k$ & 140 \\
\hline Dinar & Cumhuriyet & 159 & Emirda ̆̆ & Alibeyce & 123 \\
\hline Dinar & Çağlayan & 197 & Emirdağ & Aşağıaliçomak & 147 \\
\hline Dinar & Çakıcı & 286 & Emirdağ & Aşağıkurudere & 181 \\
\hline Dinar & Çamlı & 46 & Emirdağ & Aşağıpiribeyli & 801 \\
\hline Dinar & Çapalı & 241 & Emirdağ & Avdan & 23 \\
\hline Dinar & Çayüstü & 173 & Emirdağ & Aydınyaka & 75 \\
\hline Dinar & Çiçektepe & 1.289 & Emirdağ & Bademli & 445 \\
\hline Dinar & Çobansaray & 135 & Emirdağ & Bağlıca & 145 \\
\hline Dinar & Çürüklü & 77 & Emirdağ & Balcam & 99 \\
\hline Dinar & Dikici & 929 & Emirdağ & Başkonak & 489 \\
\hline Dinar & Doğanlı & 841 & Emirdağ & Beyköy & 50 \\
\hline Dinar & Dombay & 95 & Emirdağ & Beyören & 74 \\
\hline Dinar & Duman & 264 & Emirdağ & Burunarkaç & 24 \\
\hline Dinar & Eldere & 34 & Emirdağ & Büyüktuğluk & 102 \\
\hline Dinar & Ergenli & 54 & Emirdağ & Camili & 56 \\
\hline Dinar & Genceli & 224 & Emirdağ & Çatallı & 399 \\
\hline Dinar & Göçerli & 1.068 & Emirdağ & Çaykışla & 639 \\
\hline Dinar & Gökçeli & 38 & Emirdağ & Çiftlikköy & 423 \\
\hline Emirdağ & Dağılgan & 83 & Emirdağ & Yüreğil & 678 \\
\hline Emirdağ & Dağınık & 40 & Evciler & Akyarma & 279 \\
\hline Emirdağ & Daydali & 93 & Evciler & Altınova & 552 \\
\hline Emirdağ & Demircili & 259 & Evciler & Baraklı & 499 \\
\hline Emirdağ & Dereköy & 222 & Evciler & Bostanc1 & 174 \\
\hline Emirdağ & Ekizce & 346 & Evciler & Gökçek & 1.690 \\
\hline Emirdağ & Elhan & 299 & Evciler & Körkuyu & 160 \\
\hline Emirdağ & Emirinköyü & 121 & Evciler & Madenler & 506 \\
\hline Emirdağ & Eskiakören & 78 & Hocalar & Akçadere & 662 \\
\hline Emirdağ & Eşrefli & 296 & Hocalar & Avgancik & 279 \\
\hline Emirdağ & Gedikevi & 108 & Hocalar & Çalça & 625 \\
\hline Emirdağ & Gelincik & 78 & Hocalar & Çepni & 690 \\
\hline Emirdağ & Gözeli & 182 & Hocalar & Davulga & 586 \\
\hline Emirdağ & Güney & 33 & Hocalar & Devlethan & 585 \\
\hline Emirdağ & Güneysaray & 451 & Hocalar & Güre & 384 \\
\hline Emirdağ & Güveççi & 503 & Hocalar & İhsaniye & 147 \\
\hline Emirdağ & Hamzahacılı & 264 & Hocalar & Kocagöl & 243 \\
\hline Emirdağ & Karaağaç & 150 & Hocalar & Kozluca & 263 \\
\hline Emirdağ & Karacalar & 549 & Hocalar & Örencik & 146 \\
\hline Emirdağ & Karayatak & 66 & Hocalar & Ôrtülü & 212 \\
\hline Emirdağ & Kılıçlar & 38 & Hocalar & Uluköy & 421 \\
\hline Emirdağ & Kılıçlı Kavlaklı & 72 & Hocalar & Yağc1 & 194 \\
\hline Emirdağ & Kırkpınar & 115 & Hocalar & Yeşilhisar & 1.521 \\
\hline Emirdağ & Kuruca & 96 & İhsaniye & Ablak & 238 \\
\hline Emirdağ & Leylekli & 22 & İhsaniye & Aşağıtandır & 558 \\
\hline Emirdağ & Örenköy & 221 & İhsaniye & Ayazini & 930 \\
\hline
\end{tabular}




\begin{tabular}{|c|c|c|c|c|c|}
\hline İlçe & Köy & Nüfus & İlçe & Köy & Nüfus \\
\hline Emirdağ & Özkan & 122 & İhsaniye & Basırlar & 91 \\
\hline Emirdağ & Salihler & 130 & İhsaniye & Bayramaliler & 364 \\
\hline Emirdağ & Sığracık & 177 & İhsaniye & Beyköy & 892 \\
\hline Emirdağ & Soğukkuyu & 78 & İhsaniye & Bozhüyük & 1.728 \\
\hline Emirdağ & Suvermez & 284 & İhsaniye & Cumalı & 119 \\
\hline Emirdağ & Tabaklar & 288 & İhsaniye & Demirli & 151 \\
\hline Emirdağ & Tepeköy & 56 & İhsaniye & Eskieymir & 151 \\
\hline Emirdağ & Tezköy & 457 & İhsaniye & Eynehankuzviran & 249 \\
\hline Emirdağ & Toklucak & 56 & İhsaniye & Hacıbeyli & 922 \\
\hline Emirdağ & Topdere & 33 & İhsaniye & İğdemir & 70 \\
\hline Emirdağ & Türkmenakören & 292 & İhsaniye & Kadımürsel & 95 \\
\hline Emirdağ & Türkmenköy & 316 & İhsaniye & Karacaahmet & 1.556 \\
\hline Emirdağ & Ümraniye & 65 & İhsaniye & Kiyır & 274 \\
\hline Emirdağ & Veysel & 212 & İhsaniye & Muratlar & 700 \\
\hline Emirdağ & Yarıkkaya & 112 & İhsaniye & Oğulbeyli & 90 \\
\hline Emirdağ & Yarımca & 76 & İhsaniye & Orhanl1 & 86 \\
\hline Emirdağ & Yavuz & 76 & İhsaniye & Osmanköy & 692 \\
\hline Emirdağ & Yenikap1 & 368 & İhsaniye & Sarıcaova & 24 \\
\hline Emirdağ & Yeniköy & 453 & İhsaniye & Üçlerkayası & 425 \\
\hline Emirdağ & Yukarıkurudere & 420 & İhsaniye & Yenice & 48 \\
\hline Emirdağ & Yusufağa & 74 & İhsaniye & Yeşilyayla & 112 \\
\hline İhsaniye & Yiğitpınarı & 60 & Sandiklı & Başkuyucak & 63 \\
\hline İhsaniye & Yukarıtandır & 769 & Sandıklı & Baştepe & 551 \\
\hline İşcehisar & Alanyurt & 1.017 & Sand1klı & Bekteş & 774 \\
\hline İşcehisar & Bahçecik & 84 & Sand1klı & Celiloğlu & 78 \\
\hline İşcehisar & Cevizli & 533 & Sand1klı & Çambeyli & 370 \\
\hline İşcehisar & Çalışlar & 1.786 & Sandıklı & Çamoğlu & 53 \\
\hline İşcehisar & Çatağıl & 491 & Sandıklı & Çevrepınar & 341 \\
\hline İşcehisar & Doğanlar & 652 & Sandıklı & Çiğiltepe & 634 \\
\hline İşcehisar & Doğlat & 168 & Sandıklı & Çukurca & 50 \\
\hline İşcehisar & Karaağaç & 2.317 & Sand1kl1 & Daylik & 190 \\
\hline İşcehisar & Karakaya & 795 & Sandıklı & Dodurga & 279 \\
\hline İşcehisar & Konarı & 1.010 & Sandıklı & Dutağaç & 234 \\
\hline İşcehisar & Olukpınar & 839 & Sandıklı & Ekinhisar & 443 \\
\hline K1z1lören & Ekinova & 333 & Sandıklı & Emirhisar & 279 \\
\hline Kızılören & Gülyazı & 284 & Sand1klı & Gökçealan & 128 \\
\hline Kız1lören & Türkbelkavak & 92 & Sandıklı & Gürsu & 100 \\
\hline Kızı̈ören & Yenibelkavak & 118 & Sand1klı & Hırka & 490 \\
\hline Merkez & Alcalı & 135 & Sand1klı & Karacaören & 452 \\
\hline Merkez & Anıtkaya & 1.728 & Sandıklı & Karadirek & 509 \\
\hline Merkez & Bayramgazi & 113 & Sandıklı & Karasandıklı & 232 \\
\hline Merkez & Belkaracaören & 476 & Sandıklı & Karkın & 347 \\
\hline Merkez & Bostanl1 & 588 & Sandıklı & Kınık & 282 \\
\hline Merkez & Burhaniye & 33 & Sandıklı & Kızık & 843 \\
\hline Merkez & Çavdarlı & 1.193 & Sand1klı & Kızılca & 393 \\
\hline Merkez & Değirmendere & 662 & Sandıklı & Koçgazi & 88 \\
\hline Merkez & Gözsüzlü & 150 & Sandıklı & Koçhisar & 525 \\
\hline
\end{tabular}




\begin{tabular}{|c|c|c|c|c|c|}
\hline İlçe & Köy & Nüfus & ìlçe & Köy & Nüfus \\
\hline Merkez & Halımoru & 722 & Sandıklı & Kozvan & 345 \\
\hline Merkez & Kaplanlı & 146 & Sandıklı & Kusura & 923 \\
\hline Merkez & Karaarslan & 1.003 & Sand1klı & Menteş & 702 \\
\hline Merkez & Kızıldağ & 1.321 & Sandıklı & Nasuhoğlu & 134 \\
\hline Merkez & Kozluca & 521 & Sandıklı & Oda & 205 \\
\hline Merkez & Köprülü & 1.053 & Sandıklı & Otluk & 177 \\
\hline Merkez & Küçükkalecik & 224 & Sandıklı & Örenkaya & 1.350 \\
\hline Merkez & Olucak & 189 & Sandıklı & Örmekuyu & 95 \\
\hline Merkez & Omuzca & 138 & Sand1klı & Reşadiye & 1.016 \\
\hline Merkez & Saadet & 69 & Sandıklı & Saltık & 353 \\
\hline Merkez & Saraydüzü & 456 & Sandıkl & Selçik & 121 \\
\hline Merkez & Sarık & 741 & Sandıklı & Soğucak & 92 \\
\hline Merkez & Yarımca & 100 & Sandıklı & Sorkun & 832 \\
\hline Sandıklı & Akin & 241 & Sandıklı & Susuz & 77 \\
\hline Sandıklı & Alacami & 103 & Sandıklı & Şeyhyahşi & 43 \\
\hline Sandıklı & Alagöz & 188 & Sandıklı & Ülfeciler & 183 \\
\hline Sandıklı & Alamescit & 227 & Sandıklı & Ürküt & 226 \\
\hline Sandıklı & Arızlar & 253 & Sandıklı & Yanıkören & 56 \\
\hline Sandıklı & Asmacık & 12 & Sandıklı & Yavaşlar & 748 \\
\hline Sandıklı & Ballık & 755 & Sandıklı & Yayman & 106 \\
\hline Sandıklı & Başağaç & 462 & Sandıklı & Yolkonak & 242 \\
\hline Sandıklı & Yumruca & 84 & Şuhut & Ağzıkara & 659 \\
\hline Sinanpaşa & Akçaşar & 207 & Şuhut & Akyuva & 949 \\
\hline Sinanpaşa & Akdeğirmen & 120 & Şuhut & Anayurt & 464 \\
\hline Sinanpaşa & Ayvalı & 175 & Şuhut & Arızl & 243 \\
\hline Sinanpaşa & Balmahmut & 503 & Şuhut & Atlıhisar & 1.384 \\
\hline Sinanpaşa & Başkimse & 95 & Şuhut & Aydın & 577 \\
\hline Sinanpaşa & Boyalı & 687 & Şuhut & Bademli & 320 \\
\hline Sinanpaşa & Bulca & 949 & Şuhut & Balçıkhisar & 1.357 \\
\hline Sinanpaşa & Çalışlar & 222 & Şuhut & Başören & 751 \\
\hline Sinanpaşa & Çatkuyu & 53 & Şuhut & Bozan & 118 \\
\hline Sinanpaşa & Çayhisar & 231 & Şuhut & Çakırözü & 1.155 \\
\hline Sinanpaşa & Çobanözü & 758 & Şuhut & Çobankaya & 380 \\
\hline Sinanpaşa & Elvanpaşa & 315 & Şuhut & Dadak & 590 \\
\hline Sinanpaşa & Eyice & 164 & Şuhut & Demirbel & 161 \\
\hline Sinanpaşa & Garipce & 1.163 & Şuhut & Efe & 1.228 \\
\hline Sinanpaşa & Gezler & 154 & Şuhut & Güneytepe & 379 \\
\hline Sinanpaşa & Güney & 2.082 & Şuhut & Hallaç & 643 \\
\hline Sinanpaşa & İğdeli & 83 & Şuhut & İcikli & 473 \\
\hline Sinanpaşa & Karaca Ören & 342 & Şuhut & İlyaslı & 167 \\
\hline Sinanpaşa & Kayadibi & 722 & Şuhut & İsalı & 190 \\
\hline Sinanpaşa & Kınık & 1.172 & Şuhut & Karacaören & 601 \\
\hline Sinanpaşa & Nuh & 742 & Şuhut & Karahallı & 38 \\
\hline Sinanpaşa & Saraycık & 247 & Şuhut & Karlık & 158 \\
\hline Sinanpaşa & Tazlar & 320 & Şuhut & Kavaklı & 369 \\
\hline
\end{tabular}




\begin{tabular}{llrllr}
\hline İlçe & Köy & Nüfus & İlçe & Köy & Nüfus \\
\hline Sinanpaşa & Tokuşlar & 1.156 & Şuhut & Kayabelen & 526 \\
\hline Sinanpaşa & Yıldırım Kemal & 176 & Şuhut & Kilınçkaya & 138 \\
\hline Sinanpaşa & Yörük Mezarı & 130 & Şuhut & Koçyatağ 1 & 278 \\
\hline Sultandağ1 & Akbaba & 148 & Şuhut & Kulak & 132 \\
\hline Sultandağ1 & Çamözü & 476 & Şuhut & Mahmut & 1.652 \\
\hline Sultandağ1 & Çukurcak & 290 & Şuhut & Ortapınar & 763 \\
\hline Sultandağ1 & Doğancık & 203 & Şuhut & Oynağan & 196 \\
\hline Sultandağ1 & Karakışla & 112 & Şuhut & Paşacık & 104 \\
\hline Sultandağ1 & Kurca & 1.195 & Şuhut & Senir & 481 \\
\hline Sultandağ1 & Taşköprü & 97 & Şuhut & Tekke & 132 \\
\hline Sultandağ1 & Üçkuyu & 424 & Şuhut & Uzunpınar & 150 \\
\hline Sultandağ1 & Yakasinek & 1.386 & Şuhut & Yarışlı & 1.634 \\
\hline Sultandağ1 & Yenikarabağ & 77 & & & \\
\hline
\end{tabular}

Kaynak: TÜİK (2020) ADNKS Verileri

\section{Sonuç ve Öneriler}

İdari coğrafya kapsamında incelemesini yaptı̆̆ımız Afyonkarahisar ili konum olarak Ege Bölgesi'nin İç Batı Anadolu Bölümünde yer almakta olup Denizli, Isparta, Burdur, Eskişehir, Kütahya, Konya illeriyle idari sınırlara sahiptir. $14.016 \mathrm{~km}^{2}$ olan geniş yüzölçümüyle ülkemizin 13. büyük ili olurken ülke yüzölçümünün \%1,8'ini oluşturmaktadır. İdari sınırlarında 736.912 kişilik nüfusu barındıran Afyonkarahisar ili 52,6 kişi/ $/ \mathrm{km}^{2}$ nüfus yoğunluğu ile ülke ortalaması olan $107 \mathrm{kişi} / \mathrm{km}^{2}$ 'nin oldukça altında kalmaktadır.

Afyonkarahisar ili yerleşim tarihçesi oldukça eski olup bulunduğu konuma bağlı olarak Cumhuriyet öncesinin önemli idari birimlerinden birini oluşturmuştur. 20.04.1924 tarihinde yayımlanan Teşkilatı Esasiye ile Osmanlı Dönemi'ndeki sınırlarını koruyarak Merkez, Bolvadin, Dinar, Emirdağ ve Sandıklı kazalarından oluşmak üzere Cumhuriyet'in 67 vilayetinden biri olmuştur. Bu statüsünü komşu illerle idari sınırları değişmeden günümüze kadar devam ettirmiştir. Ancak Cumhuriyet döneminde değişik zamanlarda idari yapıda yapılan düzenlemelerle il içerisinde 13 ilçe daha kurulmuştur. İlçe merkezlerinin il merkezine olan ortalama mesafesi $70 \mathrm{~km}$ 'dir.

Afyonkarahisar ilinde 1 il merkezi, 17 ilçe merkezi ve 41 belde olmak üzere toplam 59 kentsel idari alan yer almaktadır. İl içerisinde engebeli topografyaya bağlı olarak ilçeler dağlık alanlar arasında yer alan ovalarda kurulmuştur. Ancak yer şekillerine bağlı olarak ilçelerin il merkezi ile olan bağlantılarında ulaşıma bağlı olarak bir takım zorluklar yaşanmaktadır. Bu durum il merkezinin etki sahasının daralmasına yol açar. İlçe merkezlerinin il merkezine olan ortalama mesafesi 70 km'dir. Ancak Dinar, Dazkırı, Evciler ve Başmakçı ilçelerinin il merkezlerine olan mesafeleri $100 \mathrm{~km}$ 'nin üstündedir. İl merkezine oldukça uzak olan bu ilçelerden Dinar, yakınlığı ve ulaşım kolaylığı sebebiyle komşu il olan Isparta'nın etki alanına girerken yine aynı sebebe bağlı olarak Hocalar ilçesi Uşak il merkezine, Dazkırı ve Evciler ilçeleri ise Denizli il merkezine bazı hizmet sektörlerindeki ihtiyaçlarını karşılama adına yönelmeyi tercih ederler.

İlde yer alan 18 ilçenin 12 tanesinde bir diğer kentsel idari alanı oluşturan belde yerleşmeleri bulunmaktadır. Belde yerleşmelerinin büyük çoğunluğu sahip oldukları nüfusa (5000 altı) bağlı olarak kırsal karakter göstermektedir. 12 ilçeye bağlı olarak kurulan toplam 41 belde belediyesinin Afyonkarahisar il merkezine olan ortalama mesafeleri 35,4 km olurken bağl1 oldukları ilçelerin merkezlerine olan ortalama mesafeleri ise 13,6 km'dir. 
Afyonkarahisar'da kırsal idari alan olarak değerlendirilen 422 tane köy yerleşmesi bulunmaktadır. En fazla köy yerleşmesi Osmanlı Dönemi’nden beri kaza (ilçe) özelliğini koruyan Emirdağ, Dinar, Sandıklı ilçelerinde bulunmaktadır. En son ilçe statüsü kazanan Çobanlar, Evciler ve Kızılören ilçelerindeki köy sayısı da oldukça düşüktür. İlçelerin yüzölçümleri ile köy sayıları arasında kuvvetli bir bağlantı mevcuttur. 422 köy yerleşmesinde yaşayan toplam nüfus 167.355 olurken bu değer il toplam nüfusunun \%22,7'sini oluşturmaktadır. Köylerin ortalama nüfusu 397 olurken 22 köyde nüfus 50’nin altında kalmıştır.

Önemli bir geçiş konumunda yer alan Afyonkarahisar'ın gelişimi ülke ortalamasının gerisinde kalmıştır. Bu durum üzerinde sahip olduğu dağlık yapı ile ortalama yükseltinin fazla olmasının doğurduğu sonuçlar etkili olmuştur. Ancak yakın bir zamanda sahip olduğu nüfus miktarına bağlı olarak büyükşehir statüsü kazanması beklenen ilde idari bakımdan önemli değişikliklerin meydana gelmesi kuvvetle muhtemeldir. Mevcut haliyle kırsal idari alan olarak kabul edilen köylerin kentsel idari alan olarak kabul edilen mahalle statüsüne dönüşümü gerçekleşecektir. Ancak bu yerleşmeler sosyoekonomik bakımdan uzun dönem köy özelliklerini korumaya devam edeceklerdir. Diğer yandan belde yerleşmeleri ise bağlı bulundukları ilçelerin mahalleleri konumuna dönüşecektir. Bu kapsamlı değişikliklerin Afyonkarahisar'da ilçe idari sınırlarının değişimi sonucunu getirmesi kaçınılmaz olarak görünmektedir.

\section{Kaynakça}

Baykara, T. (1988). Anadolu'nun tarihi coğrafyasına giriş. Ankara.

Çevre Durum Raporu (2019), Afyonkarahisar ili 2019 yılı çevre durum raporu, Afyonkarahisar Valiliği.

Daşdemir, L. (2004). Cumhuriyet döneminde Afyon. Anadolu'nun Kilidi Afyon içinde (ss.132149). 21, Afyon: Afyon Valiliği Yayın.

Daşdemir, L. ve Uyan, M., (2001), "Cumhuriyet döneminde idari yapı", Afyonkarahisar Kütüğü 1 İkinci Bölüm (ss. 211-243), Afyon Kocatepe Üniversitesi Yayın 35.

Emecen, F., Şahin İ., (1999). Osmanlı Taşra Teşkilatının Kaynaklarından 957-958(1550-1551) Tarihli Sancak Tevcih Defteri I. Belgeler, 53-123.

HGM (2021), Harita Genel Komutanlığına ait harita.gov.tr adresinden (Erişim Tarihi:13.01.2021)

İçişleri Bakanlığı İller İdaresi Genel Müdürlüğü, https://www.icisleri.gov.tr/illeridaresi/il-ve-ilce-kurulus-tarihleri (Erişim Tarihi:14.01.2021)

İnalc1k, H. (1995). "Eyalet", TDV Íslam Ansiklopedisi, 11, 548-550.

Karagel, H., Üçecam Karagel, D., (2014), Türkiye'de idari yapılanma sürecinin coğrafya analizi, 2 (Special Issue), (ss. 10-32).

Karazeybek, M. (2004). "Osmanlılar döneminde Afyonkarahisar", Anadolu'nun Kilidi Afyon, 21, 76-112, Afyon Valiliği Yayın, Afyon.

Kocaman, S., (2014), Kars ilinin idari coğrafya analizi, The Journal of Academic Social Science Studies, 29, 271-292.

Koçman, A. (1993). Türkiye İklimi. İzmir: Ege Üniversitesi Edebiyat Fakültesi Yayınlar1 72.

Koday, Z., \& Erhan, K. (2008). Erzurum İlinin İdari Coğrafya Analizi. Atatürk Üniversitesi Edebiyat Fakültesi Sosyal Bilimler Dergisi, 8, (41), 231-248.

Meteoroloji Genel Müdürlüğü (2020), www.mgm.gov.tr adresinden (Erişim Tarihi:03.01.2021)

Özcan, K. (2005). Ortaçağda anadolu'nun idari coğrafyasına bakış anadolu'da Selçuklu idari birimleri. Coğrafi Bilimler Dergisi, 3 (1), 73-99. 
Özçağlar, A. (2003), Türkiye'de yapılan bölge ayrımları ve bölge planlama üzerindeki etkileri, Coğrafi Bilimler Dergisi, 1 (1), 3-18.

Özçağlar, A. (2005). Türkye'de Mülki İdare Bölümlerinin İdari Coğrafya Analizi. Coğrafi Bilimler Dergisi, 3 (1), 1-25.

Resmi Gazete (1924), Köy kanunu, Ankara.

Resmi Gazete (1985a), 3194 say1lı imar kanunu, Ankara.

Resmi Gazete (2005) 5393 sayılı belediye kanunu, Ankara.

Satıcı, E. (2008). 19. Yüzyılda Hüdavendigar Eyaleti, (Doktora Tezi). Ankara Üniversitesi Sosyal Bilimler Enstitüsü, Yakınçağ Tarihi ABD, Ankara.

Solak, İ. (2012). Osmanlı devletinde taşra teşkilatı. E. Gündüz içinde, Osmanlı Teşkilat Tarihi El Kitabı (77-112). Ankara: Grafiker Yayınları.

Şahin, G. (2002). XVII. Yüzyılın sonlarında Afyonkarahisar sancağının idari ve fiziki yapısı. Tarih Incelemeleri Dergisi, 17, 2, 39-57.

TÜİK, (2020), ADNKS Sonuçları www.tuik.gov.tr (Erişim tarihi: 10.02.2021).

Uçar, H., (2007), Çevre sorunları açısından Afyonkarahisar, (Yüksek lisans tezi), Afyon Kocatepe Üniversitesi Sosyal Bilimler Enstitüsü, Afyonkarahisar.

Yazıc1, H., Koca, N., Koca, M. K., (2010). Coğrafi faktörlerin mülki yapılanma üzerindeki etkilerine bir örnek: Afyonkarahisar ili. Amme idaresi Dergisi, 43, (3) 109 - 124.

Yılmaz, Ö. (1999). Afyon ve çevresinin iklim özellikleri. Afyonkarahisar: Afyon Kocatepe Üniversitesi Basımevi.

\section{ETİK ve BİLIMSEL İLKELER SORUMLULUK BEYANI}

$\mathrm{Bu}$ çalışmanın tüm hazırlanma süreçlerinde etik kurallara ve bilimsel atıf gösterme ilkelerine riayet edildiğini yazar(lar) beyan eder. Aksi bir durumun tespiti halinde Afyon Kocatepe Üniversitesi Sosyal Bilimler Dergisi'nin hiçbir sorumluluğu olmayıp, tüm sorumluluk makale yazarlarına aittir. 